GRASAS Y ACEITES 71 (4)

October-December 2020, e379

ISSN-L: 0017-3495

https://doi.org/10.3989/gya.0913192

\title{
Antioxidant activity, volatile compounds and fatty acid compositions of Cephalaria syriaca seeds obtained from different regions in Turkey
}

\author{
C. Kavak ${ }^{\mathrm{a}}$ and A. Baştürk ${ }^{\mathrm{a}, 凶}$ \\ ${ }^{\mathrm{a}}$ Van Yüzüncü Yll University, Faculty of Engineering, Department of Food Engineering, 65080Van, Turkey. \\ ${ }^{凶}$ Corresponding author: ayhanbasturk@gmail.com
}

Submitted: 19 September 2019; Accepted: 31 October 2019; Published online: 14 October 2020

SUMMARY: Crude oil yield, fatty acid composition, volatile compounds, antioxidant activity and some characteristics of Cephalaria syriaca seeds collected from different locations in Turkey were studied. Antioxidant capacity was determined by DDPH and ABTS tests and the results were in the range of $18.8-67.3 \%$ and $0.0-41.8$ mmol Trolox eq g ${ }^{-1} \mathrm{DW}$, respectively; while total phenolic contents were between 4339-11907 $\mathrm{mg} \mathrm{GAE} \mathrm{kg}^{-1}$. The average $\alpha$-tocopherol content was found to be in the range of $54-467 \mathrm{mg} \mathrm{kg}^{-1}$. Oil yield was between $11.2-24.0 \%$. Oleic and linoleic acids were the predominant fatty acids. A total of 30 different volatile compounds were identified in the samples, mostly consisting of alcohols and aldehydes. The results of this study showed that Cephalaria syriaca seeds can be considered as alternative raw material in the production of edible oil, and can be used as a source of natural antioxidants and food additives.

KEYWORDS: ABTS; Acetaldehyde; Cephalaria syriaca; DPPH; GC-MS; Hexanal; Phenolics

RESUMEN: Actividad antioxidante, compuestos volátiles y composición en ácidos grasos de semillas de Cephalaria syriaca obtenidas de diferentes regiones de Turquía. Se estudió el rendimiento de aceite crudo, la composición en ácidos grasos, los compuestos volátiles, la actividad antioxidante y algunas características de las semillas de Cephalaria syriaca recolectadas en diferentes lugares de Turquía. La capacidad antioxidante se determinó mediante pruebas DDPH y ABTS y los resultados estuvieron en el rango de 18.8-67.3\% y 0.0-41.8 mmol Trolox eq $\mathrm{g}^{-1} \mathrm{DW}$, respectivamente, mientras que el contenido fenólico total estuvo entre 4339-11907 mg GAE kg ${ }^{-1}$. El contenido promedio de $\alpha$-tocoferol se encontró en el rango de $54-467 \mathrm{mg} \mathrm{kg}^{-1}$. El rendimiento del aceite estuvo entre 11,2-24,0\%. Los ácidos oleico y linoleico fueron los ácidos grasos predominantes. Se identificaron un total de 30 compuestos volátiles diferentes en las muestras, principalmente alcoholes y aldehídos. Los resultados de este estudio mostraron que las semillas de Cephalaria syriaca pueden considerarse como materia prima alternativa en la producción de aceite comestible, y pueden usarse como fuente de antioxidantes naturales y aditivos alimentarios.

PALABRAS CLAVE: ABTS; Acetaldehído; Cephalaria syriaca; DPPH; Fenólicos; GC-MS; Hexanal

ORCID ID: Kavak C https://orcid.org/0000-0003-4542-7473, Baştürk A https://orcid.org/0000-0001-7701-9306

Citation/Cómo citar este artículo: Kavak C, Baştürk A. 2020. Antioxidant activity, volatile compounds and fatty acid compositions of Cephalaria syriaca seeds obtained from different regions in Turkey. Grasas Aceites 71 (4), e379. https://doi.org/10.3989/gya.0913192

Copyright: (C2020 CSIC. This is an open-access article distributed under the terms of the Creative Commons Attribution 4.0 International (CC BY 4.0) License. 


\section{INTRODUCTION}

The interest in different edible oils, including plant seeds with high nutrition value, industrial and pharmaceutical significance, has recently increased. Since oils obtained from different sources generally have different fat compositions, no oil source alone is considered sufficient for all purposes. This has brought about the demand for new oil sources. In line with the increasing demand and scientific studies on the nutritional properties of these oils, determining their quality properties and composition from non-conventional seeds has gained importance (Nehdi, 2011).

Cephalaria Schrad. ex Roem. and Schult. originates from the Greek word for head (kephale). Cephalaria species have flowers which are densely arranged on the floral receptacle in the form of a head. There are 94 endemic plant species which are members of the Cephalaria (Dipsacaceae) family and it has a wide distribution in regions of the Mediterranean, Balkan, Middle East and North Africa (Davis, 1970; Gokturk et al., 2003). Of these plant species which belong to the Cephalaria family, 29 show a wide distribution in Turkey (Gokturk and Sumbul, 2014). It has been reported that Cephalaria species have various biological properties including antibacterial, antifungal, antioxidant and cytotoxic activities (Kirmizigül et al., 1996; Mustafaeva et al., 2008; Pasi et al., 2009; Sarıkahya and Kırmızıül, 2010). Therefore, it is used in medicine, agriculture and veterinary medicine (Kayce and Kirmizigül, 2010). Cephalaria syriaca L. (CS), pelemir in Turkish, is predominantly found in the southeastern region of Turkey as a weed in cereal fields. The oil of this plant seed is sometimes extracted and used in the baking industry to enhance the quality of bakery products (Yazicioğlu et al., 1978). There is no extensive study on the antioxidant activity, volatile compound or fatty acid composition of CS seeds, which are widely grown in Turkey.

The aim of this study was to determine and compare crude oil yield, fatty acid composition, volatile compounds, antioxidant activity and some characteristics of Cephalaria syriaca seeds collected from different altitudes and locations in Turkey.

\section{MATERIALS AND METHODS}

\subsection{Plant materials and chemicals}

The CS seeds used in the study were collected from different locations, at different altitudes, longitudes and latitudes, as determined by a Global Positioning System (GPS), at their maturation stage from June to August, 2017, according to their maturation levels. Samples were collected from the provinces of Mardin, Van, Gaziantep, Bitlis, Erzincan, Diyarbakır, A ğrı, Şanlıurfa, Siirt, Muş and Batman,

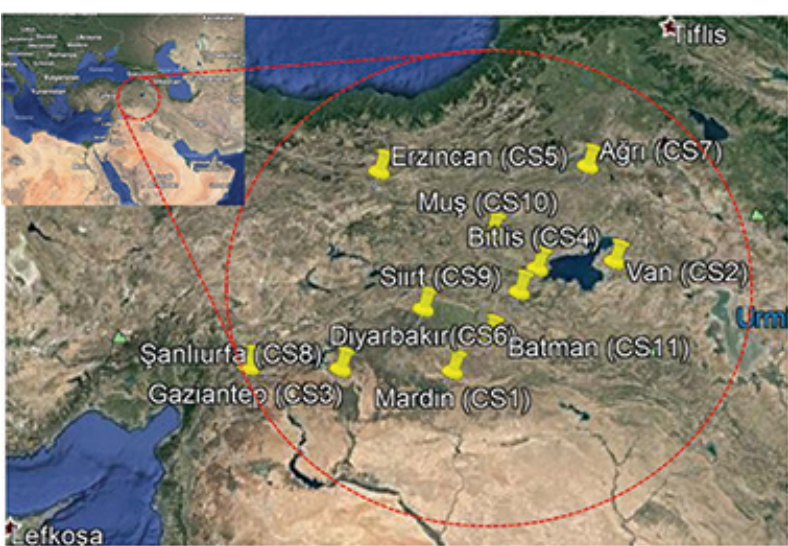

FIGURE 1. Map of locations where the samples of CS (Cephalaria syriaca) seeds collected.

all located in Turkey (Figure 1). Three groups of samples, each consisting of fifteen plants, were collected per location. Seed samples were coded as $\mathrm{CS}_{1}, \mathrm{CS}_{2} \ldots$, and $\mathrm{CS}_{11}$, according to the locations from where they were collected, as given in Table 1. Folin-Ciocalteu's reagent, methanol, n-hexane, isooctane, potassium persulfate methanol, isooctane, potassium persulfate, $\alpha-, \beta-, \gamma$ - and $\delta$-tocopherol standards were obtained from Merck (Darmstadt, Germany). 2,2-diphenyl-1picrylhydrazyl (DPPH), 2,2+-azinobis-3-ethylbenzothiazoline-6-sulfonic acid, 5-methyl 2 hexanone, trolox and standards of fatty acid methyl esters (37 FAME mix) were obtained from Sigma Chemical Co. (Sigma-Aldrich $\mathrm{GmbH}$, Sternheim, Germany).

\subsection{Preparation of methanolic extract}

$9.5 \mathrm{~mL}$ methanol were added to $5 \mathrm{~g}$ hexanedefatted ground Cephalaria seed, and the contents were homogenized with a homogenizer (Heidolph, SilentCrusher M, Schwabach, Germany) at 10.000 $\mathrm{rpm}$ for $15 \mathrm{~s}$. The homogenized sample was agitated at room temperature for $2 \mathrm{~h}$ at $200 \mathrm{rpm}$ in a circular shaker (Heidolph, unimax 1010, Kelheim, Germany). Then, the contents were centrifuged at $8000 \times g$ for $10 \mathrm{~min}$ at $4{ }^{\circ} \mathrm{C}$. Following centrifugation, the supernatant was separated from the residue, and the residue was subjected to the same treatment in duplicate. The supernatants obtained at the end of extraction were combined and completed to $25 \mathrm{~mL}$ with methanol.

\subsection{Seed analyses}

\subsubsection{Proximate analysis of seeds}

The recommended methods of the Association of Official Analytical Chemists AOAC, (2005) were adopted to determine the levels of moisture, ash, crude protein and crude oil. The moisture content 
TABLE 1. Geographical information on location of Cephalaria syriaca samples collected

\begin{tabular}{lcccc}
\hline Cephalariasyriaca (location) & Code & Altitude, m & Latitude & Longitude \\
\hline Mardin & $\mathrm{CS}_{1}$ & 596 & $37^{\circ} 15^{\prime} 07.51^{\prime \prime}$ & $40^{\circ} 43^{\prime} 36.76^{\prime \prime}$ \\
Van & $\mathrm{CS}_{2}$ & 1668 & $38^{\circ} 34^{\prime} 52.93^{\prime \prime}$ & $43^{\circ} 17^{\prime} 56.65^{\prime \prime}$ \\
Gaziantep & $\mathrm{CS}_{3}$ & 980 & $37^{\circ} 02^{\prime} 41.84^{\prime \prime}$ & $37^{\circ} 17^{\prime} 08.84^{\prime \prime}$ \\
Bitlis & $\mathrm{CS}_{4}$ & 1703 & $38^{\circ} 25^{\prime} 50.31^{\prime \prime}$ & $42^{\circ} 07^{\prime} 47.02^{\prime \prime}$ \\
Erzincan & $\mathrm{CS}_{5}$ & 1376 & $39^{\circ} 42^{\prime} 26.63^{\prime \prime}$ & $39^{\circ} 29^{\prime} 10.32^{\prime \prime}$ \\
Diyarbakır & $\mathrm{CS}_{6}$ & 718 & $37^{\circ} 53^{\prime} 31.99^{\prime \prime}$ & $40^{\circ} 09^{\prime} 20.50^{\prime \prime}$ \\
Ağr & $\mathrm{CS}_{7}$ & 1687 & $39^{\circ} 42^{\prime} 04.42^{\prime \prime}$ & $43^{\circ} 02^{\prime} 14.46^{\prime \prime}$ \\
Şanliurfa & $\mathrm{CS}_{8}$ & 457 & $37^{\circ} 06^{\prime} 27.54^{\prime \prime}$ & $38^{\circ} 54^{\prime} 38.55^{\prime \prime}$ \\
Siirt & $\mathrm{CS}_{9}$ & 711 & $37^{\circ} 56^{\prime} 07.09^{\prime \prime}$ & $41^{\circ} 53^{\prime} 58.22^{\prime \prime}$ \\
Muş & $\mathrm{CS}_{10}$ & 1584 & $38^{\circ} 48^{\prime} 12.61^{\prime \prime}$ & $41^{\circ} 33^{\prime} 27.65^{\prime \prime}$ \\
Batman & $\mathrm{CS}_{11}$ & 748 & $37^{\circ} 53^{\prime} 06.18^{\prime \prime}$ & $41^{\circ} 14^{\prime} 52.27^{\prime \prime}$ \\
\hline
\end{tabular}

was determined by drying the samples at $105^{\circ} \mathrm{C}$ to constant weight. The ash content was determined in a laboratory furnace at $600{ }^{\circ} \mathrm{C}$, and the temperature was increased gradually. Nitrogen content was determined by using the Kjeldhal method. Crude oil was obtained by the Soxhlet extraction method by exhaustively extracting $10 \mathrm{~g}$ of each sample in a Soxhlet apparatus using hexane as the extractant. Each measurement was performed in triplicate and the results were averaged.

\subsubsection{Determination of total phenolic content}

The phenolic content (TPC) of CS seed extracts was determined using the Folin-Ciocalteu reagent (Singleton and Rossi, 1965). Samples $(0.4 \mathrm{~mL}$, two replicates) were placed in test tubes; $2 \mathrm{~mL}$ of FolinCiocalteu's reagent and $1.6 \mathrm{~mL}$ of sodium carbonate $(7.5 \%)$ were added. The tubes were agitated and allowed to stand for $60 \mathrm{~min}$. Absorption was measured at $765 \mathrm{~nm}$ in a UV-spectrophotometer (Agilent 8453, Agilent technologies, CA, USA). Gallic acid was used as a standard for the calibration curve $(y=0.0063 \mathrm{x}+0.049)$. The total phenolic content was expressed as gallic acid equivalent (mg GAE/kg dry extract).

\subsubsection{Antioxidant activity tests}

DPPH radical scavenging assay. The DPPH free radical removal activity of the CS seed extracts was determined by the Blois method (Blois, 1958). Prior to the procedure, the methanolic DPPH solution was prepared for analysis. $0.0065 \mathrm{~g}$ DPPH were weighed and completed to $250 \mathrm{~mL}$ with methanol $(0.025 \mathrm{~g} / \mathrm{L}$ methanol). For the analysis, $0.1 \mathrm{~mL} \mathrm{CS}$ seed extract was prepared and a $3.9 \mathrm{~mL}$ DPPH solution was added and mixed using a vortex and kept for 60 minutes at room temperature in the dark. At the end of this period, the absorbance of the UV spectrophotometer was read at $515 \mathrm{~nm}$. In the control sample, the spectrophotometer was reset with pure methanol using solvent instead of sample. At the end of the $60 \mathrm{~min}$, the amount of DPPH inhibited in the reaction medium was determined using Equation 1.

$$
\mathrm{I}=\frac{\mathrm{A}_{2}-\mathrm{A}_{1}}{\mathrm{~A}_{2}} \times 100
$$

Eqn. 1

I = DPPH inhibited by the sample, $\%$

$\mathrm{A}_{1}=$ absorbance of the sample

$\mathrm{A}_{2}=$ absorbance of the control

ABTS assay. ABTS analysis was performed using the method proposed by Re et al., (1999). Measurements were carried out spectrophotometrically by observing the disappearance of the ABTS radical, a stable blue-green compound. The reaction between ABTS and potassium persulfate yields a blue-green ABTS ${ }^{+}$chromophore. $7 \mathrm{mmol}$ of ABTS (2,2+-azinobis-3-ethylbenzothiazoline-6-sulfonic acid) and $2.45 \mathrm{mmol}$ potassium persulfate were reacted at room temperature in the dark for $12-16 \mathrm{~h}$ to yield the stock $\mathrm{ABTS}^{+}$radical cation. The obtained $\mathrm{ABTS}^{+}$radical cation was diluted with ethanol to give $0.70 \pm 0.02$ absorbance at $734 \mathrm{~nm}$. Then, $20 \mu \mathrm{L}$ of extract were mixed with $1980 \mu \mathrm{L}$ $\mathrm{ABTS}^{+}$radical cation for 6 minutes at room temperature in the dark and measured in the UV spectrophotometer at $734 \mathrm{~nm}$. The results were calculated using the Trolox standard curve $(y=38.484 x-2.602)$ and Equation 2, and were presented as mmol trolox eq/g dry weight.

Inhibition $\%=\frac{\mathrm{A}_{6}-\mathrm{A}_{1}}{\mathrm{~A}_{1}} \times 100$

Eqn. 2

$\mathrm{A}_{6}:$ Absorbance at the 6th min

$\mathrm{A}_{1}$ : Absorbance at the 1 st min 


\subsubsection{Determination of volatile compounds}

The determination of volatile compounds was carried out by GC-MS according to Krist et al., (2006), with some modifications. Analyses were performed in 3 replicates. Before starting the analysis, $0.1 \mathrm{~mL} 5$-methyl 2 hexanone was completed to $10 \mathrm{~mL}$ with pure water by the internal standard (IS) and prepared for analysis. 3 grams of ground seeds were placed in $30 \mathrm{~mL}$ vials, and $10 \mathrm{~mL}$ pre-boiled and cooled pure water were added and homogenized using a homogenizer (Heidolph Silent Crusher M, Schwabach, Germany) at $13000 \mathrm{rpm}$. Then, the solution was added to $10 \mu \mathrm{L}$ internal standard and a magnetic stirrer was added. After the lids of the vials were sealed and conditioned for $5 \mathrm{~min}$ at $40^{\circ} \mathrm{C}$ in the heating block by immersing them in an appropriate fiber $(50 / 30 \mu \mathrm{m}$-thick, DVB/CAR/PDMS as the absorbant), they were left to absorb the volatile components in the peak space for 40 minutes in a heated magnetic stirrer set to $40{ }^{\circ} \mathrm{C}$ and $140 \mathrm{rpm}$. At the end of this period, the fiber was held at the injection port of the gas chromatography device for $5 \mathrm{~min}$ to pass the fiber-holding volatile components to the GC-MS system column. A TRB-5MS (30 m length, $0.250 \mathrm{~mm}$ internal diameter, $0.25 \mu \mathrm{m}$ film thickness) capillary column was used in the analyses. The operating conditions were set as follows: injection block temperature of $250{ }^{\circ} \mathrm{C}$; detector temperature of $250^{\circ} \mathrm{C}$; carrier gas was He; flow rate at $1 \mathrm{~mL} / \mathrm{min}$; temperature of the $\mathrm{MS}$ source was $230{ }^{\circ} \mathrm{C}$; MS quadrupole temperature of $150{ }^{\circ} \mathrm{C}$; injection mode was splitless; electron energy of $70 \mathrm{eV}$; mass range of 15-210 atomic mass units. The oven temperature was held at $40{ }^{\circ} \mathrm{C}$ for $2 \mathrm{~min}$, raised from 40 to $70^{\circ} \mathrm{C}$ with $5^{\circ} \mathrm{C}$ increments per min, held at $70{ }^{\circ} \mathrm{C}$ for $1 \mathrm{~min}$, raised from 70 to $240{ }^{\circ} \mathrm{C}$ with $10{ }^{\circ} \mathrm{C}$ increment per min, and held at $240{ }^{\circ} \mathrm{C}$ for $30 \mathrm{~min}$. Then, identifications of the components in the chromatogram were compared with the information in the Wiley and NIST libraries and the calculated retention indexes (RI). In addition, the mass spectra of the defined components and the mass spectra of the internal standard were used to calculate the amounts $(\mu \mathrm{g} / \mathrm{kg})$.

\subsection{Analysis of seed oils}

\subsubsection{Extraction of oils}

The oil samples required for planned analyses including fatty acid composition, peroxide value (PV), free fatty acid (FFA), tocopherol and color parameters were obtained by cold extraction. $130 \mathrm{~mL}$-hexane were added to ground CS $(35 \mathrm{~g})$ and kept in the circular shaker at $180 \mathrm{rpm}$ for $2 \mathrm{~h}$. The extracts were filtered and the hexane was evaporated at $40^{\circ} \mathrm{C}$ in a rotary evaporator. The seed oils were stored at $+4{ }^{\circ} \mathrm{C}$ in the dark until use.

\subsubsection{Determination of FFA and PV}

The methods recommended by AOCS, (1989b) were adopted to determine FFA contents (method Ca 5a-40/93) and PV (method Cd 8-53).

\subsubsection{Fatty acid composition}

First, fatty acid methyl esters (FAMEs) were formed as described by Basturk et al., (2007). After formation of the methyl esters, $1 \mathrm{~mL}$ from the clear upper phase was injected into the injection port of the device, a QP 2010 Ultra Shimadzu GC-MS with MS detector combined with a FID detector. The column details and working conditions were as follows: DB-23 column (60 m x $0.25 \mathrm{~mm}, 0.25 \mu \mathrm{m})$; carrier gas was He at a total flow of $36.6 \mathrm{~mL} / \mathrm{min}$; the column flow was $0.66 \mathrm{~mL} / \mathrm{min}$; linear speed was $21.2 \mathrm{~cm} / \mathrm{sec}$ at a split ratio of 50 . The initial temperature was $80{ }^{\circ} \mathrm{C}$, which was increased at $10{ }^{\circ} \mathrm{C} /$ min until the final temperature of $220^{\circ} \mathrm{C}$; injection and detection temperatures were $250{ }^{\circ} \mathrm{C}$. The total analysis time was $34 \mathrm{~min}$ and the ion source temperature was $200{ }^{\circ} \mathrm{C}$. Fatty acid methyl esters were identified by chromatography with authentic standards (Sigma) and from the NIST 05 MS Library Database. Quantification of the fatty acid methyl ester profiles was made by considering the relative peak areas, expressed as the relative percentage of the individual area of each one as related to the total area of compounds in the chromatogram. FAMEs analyses were performed in 3 replicates.

\subsubsection{Determination of $\alpha$-tocopherol}

The tocopherol content of the samples was determined on a HPLC device (Shimadzu, Kyoto, Japan) according to the AOCS Official Method (Ce 8-89) (AOCS, 2003). In CS samples, the oil samples obtained by cold extraction were diluted with n-hexane at a ratio of $1: 10$, then filtered through a $0.45 \mu \mathrm{m}$ (MillipareMillex-LCR Hydrophilic PTFE) filter and injected into the device. The HPLC operating conditions were as follows: LiChrosorb Si60 column $(250 \times 4 \mathrm{~mm}$, ID) $5 \mu \mathrm{m}$, at a flow rate of $1 \mathrm{~mL} / \mathrm{min}$ (isocratic flow); the mobile phase contained hexane: isopropyl alcohol (99:1); wavelength was $295 \mathrm{~nm}$; column temperature was $25{ }^{\circ} \mathrm{C}$. The compounds appearing in the chromatograms were identified as retention times and spectral data by comparison with standards of $\alpha-, \beta-, \gamma$ - and $\delta$-tocopherols. Results were expressed in $\mathrm{mg} / \mathrm{kg}$ oil. The measurements were taken in triplicate.

\subsubsection{Color measurement}

The $\mathrm{L}^{*}, \mathrm{a}^{*}, \mathrm{~b}^{*}$ color values of the samples were determined by using a colorimeter (CR-400 Konica, Minolta, Tokyo, Japan). First, calibration of the 
device was carried out on a white plate and black hole provided by the manufacturer. For absolute measurements, approximately $20 \mathrm{~mL}$ of oil sample were placed on the measuring head and three readings were taken in different positions. The average values of $\mathrm{L}^{*}, \mathrm{a}^{*}$, and $\mathrm{b}^{*}$ were given based on three subsequent readings.

\subsection{Statistical analysis}

Statistical analyses were performed using SPSS software (version 20.0 for Windows, SPSS Inc., Chicago, Illinois). The collected data from the different dependent variables were analyzed statistically according to the analysis of variance with three replicates as a general test at each location. The differences between mean values were analyzed using Duncan's multiple range tests at the 0.05 level of significance.

\section{RESULTS AND DISCUSSION}

\subsection{Physicochemical properties of CS seeds}

A proximate composition of CS seeds is given in Table 2. The crude fat content was between 11.2$24.0 \%$, depending on harvest location. $\mathrm{CS}_{1}$ showed the highest fat content, followed by $\mathrm{CS}_{11}$. Similar ratios were obtained in previous studies. The fat content of CS was previously reported to be between 24.9 and $25.8 \%$, by Yazicioğlu et al., (1978), as $25.14 \%$ by Uslu, (2016), $30.3 \%$ by Bretagnolle et al., (2016), 19.32-25.15\% by Rahimi et al., (2019) and between 19.08 and $23.99 \%$ by (Katar et al., 2012). The fat content obtained in the present study was generally consistent with the previously reported results. However, it changed within a relatively large range depending on the harvest location.
The moisture content of the seeds was found to be in the range of 7.6-13.8\%. Uslu (2016) found the moisture content as $6.08 \%$. $\mathrm{CS}_{2}$ showed the highest moisture content; while that of $\mathrm{CS}_{10}$ was the lowest. There was no significant difference among the group of samples of $\mathrm{CS}_{3}, \mathrm{CS}_{4}$ and $\mathrm{CS}_{7}$, which was lower in moisture content compared to $\mathrm{CS}_{1}, \mathrm{CS}_{5}$, $\mathrm{CS}_{6}, \mathrm{CS}_{8}, \mathrm{CS}_{9}$ and $\mathrm{CS}_{11}$ group. The ash contents of the samples were determined to be in the range of $5.05-7.58 \%$ in the present study. These values were similar to the ash ratio of $5.34 \%$ as determined by Uslu (2016). The protein content detected in the CS samples was in the range of $14.7-21.2 \%$. The highest protein yields were in $\mathrm{CS}_{11}, \mathrm{CS}_{6}, \mathrm{CS}_{10}$ and $\mathrm{CS}_{1}$ samples, in descending order. Protein contents were reported in previous studies as $15.54 \%$ by Uslu (2016) and $16.4-22.5 \%$ by Altıniğne and Saygin (1985), and were in agreement with this study. The proximate composition of seeds may vary depending on many factors including harvest time, local weather conditions, geographical location, etc.

\subsection{Total phenolic content and antioxidant activity of CS seeds}

TPC and antioxidant activity of CS seeds are given in Table 3. The highest TPC were found in $\mathrm{CS}_{1}, \mathrm{CS}_{7}$, $\mathrm{CS}_{10}$ and $\mathrm{CS}_{11}$ samples, in descending order. The two groups that differed were $\mathrm{CS}_{1}, \mathrm{CS}_{2}, \mathrm{CS}_{4}, \mathrm{CS}_{5}, \mathrm{CS}_{7}$, $\mathrm{CS}_{8}, \mathrm{CS}_{10}$ and $\mathrm{CS}_{11}$, which were significantly different from $\mathrm{CS}_{3}, \mathrm{CS}_{6}$ and $\mathrm{CS}_{9}(\mathrm{P}<0.05)$. Sarikahya et al., (2015) determined the total amount of phenolic compounds as 57-3037 $\mathrm{mg} \mathrm{GAE} / \mathrm{kg}$ in the aerial parts of ten different Cephalaria species, except for C. syriaca. Of these species, C.tchihatchewii, C.aristata and C. speciosa were found to have the highest phenolic contents (3037, 2907 and $2658 \mathrm{mg}$

TABLE 2. Proximate composition of CS seeds

\begin{tabular}{lcccc}
\hline Sample & Oil \% & Protein (\%) & Moisture\% & Ash\% \\
\hline $\mathbf{C S}_{\mathbf{1}}$ & $23.99 \pm 0.52^{\mathrm{f}}$ & $20.00 \pm 1.94^{\mathrm{de}}$ & $10.85 \pm 0.88^{\mathrm{de}}$ & $6.26 \pm 0.52^{\mathrm{abc}}$ \\
$\mathbf{C S}_{\mathbf{2}}$ & $19.22 \pm 0.27^{\mathrm{e}}$ & $16.46 \pm 0.35^{\mathrm{ab}}$ & $13.75 \pm 0.89^{\mathrm{f}}$ & $5.64 \pm 0.52^{\mathrm{ab}}$ \\
$\mathbf{C S}_{\mathbf{3}}$ & $16.67 \pm 0.59^{\mathrm{d}}$ & $19.51 \pm 1.15^{\mathrm{cde}}$ & $9.82 \pm 0.21^{\mathrm{bcd}}$ & $6.65 \pm 0.59^{\mathrm{bc}}$ \\
$\mathbf{C S}_{\mathbf{4}}$ & $19.33 \pm 0.49^{\mathrm{e}}$ & $15.40 \pm 0.37^{\mathrm{a}}$ & $9.53 \pm 0.54^{\mathrm{bc}}$ & $5.59 \pm 0.34^{\mathrm{ab}}$ \\
$\mathbf{C S}_{\mathbf{5}}$ & $18.52 \pm 0.42^{\mathrm{e}}$ & $14.67 \pm 1.00^{\mathrm{a}}$ & $11.14 \pm 0.25^{\mathrm{e}}$ & $6.88 \pm 0.58^{\mathrm{bc}}$ \\
$\mathbf{C S}_{\mathbf{6}}$ & $15.03 \pm 0.54^{\mathrm{cd}}$ & $21.08 \pm 0.83^{\mathrm{e}}$ & $10.98 \pm 0.31^{\mathrm{de}}$ & $6.78 \pm 0.91^{\mathrm{bc}}$ \\
$\mathbf{C S}_{\mathbf{7}}$ & $13.29 \pm 0.28^{\mathrm{bc}}$ & $16.38 \pm 0.31^{\mathrm{ab}}$ & $8.97 \pm 0.48^{\mathrm{b}}$ & $6.97 \pm 0.62^{\mathrm{bc}}$ \\
$\mathbf{C S}_{\mathbf{8}}$ & $11.95 \pm 2.01^{\mathrm{ab}}$ & $18.61 \pm 0.16^{\mathrm{cd}}$ & $10.20 \pm 0.16^{\mathrm{cde}}$ & $7.58 \pm 0.58^{\mathrm{c}}$ \\
$\mathbf{C S}_{\mathbf{9}}$ & $11.18 \pm 0.82^{\mathrm{a}}$ & $17.61 \pm 0.20^{\mathrm{bc}}$ & $10.38 \pm 0.31^{\text {cde }}$ & $7.25 \pm 0.54^{\mathrm{c}}$ \\
$\mathbf{C S}_{\mathbf{1 0}}$ & $19.85 \pm 0.38^{\mathrm{e}}$ & $20.48 \pm 0.55^{\mathrm{de}}$ & $7.62 \pm 0.28^{\mathrm{a}}$ & $5.05 \pm 1.19^{\mathrm{a}}$ \\
$\mathbf{C S}_{\mathbf{1 1}}$ & $22.47 \pm 1.00^{\mathrm{f}}$ & $21.22 \pm 1.12^{\mathrm{e}}$ & $10.62 \pm 0.48^{\text {cde }}$ & $6.54 \pm 0.25^{\mathrm{abc}}$ \\
\hline
\end{tabular}

*Small letters indicate significant differences within each column for the mean \pm SD values calculated from three determinations by one-way ANOVA and Duncan's test $(\mathrm{P} \leq 0.05)$. Cephalaria syriaca L. samples according to location; $\mathrm{CS}_{1}$ : Mardin, $\mathrm{CS}_{2}$ : Van, $\mathrm{CS}_{3}$ : Gaziantep, $\mathrm{CS}_{4}$ : Bitlis, $\mathrm{CS}_{5}$ : Erzincan, $\mathrm{CS}_{6}$ : Diyarbakir, $\mathrm{CS}_{7}$ : Agri, $\mathrm{CS}_{8}$ : Sanliurfa, $\mathrm{CS}_{9}$ : Siirt, $\mathrm{CS}_{10}$ : Mus, $\mathrm{CS}_{11}$ : Batman. 
TABLE 3. Total phenolic content and antioxidant activity of CS seeds

\begin{tabular}{lccc}
\hline Sample & $\begin{array}{c}\text { Total Phenolic Content } \\
(\mathbf{m g} \text { GAE/kg dry seeds) }\end{array}$ & DPPH (Inhibition \%) & ABTS (mMolTrol. eq./gDW) \\
\hline $\mathbf{C S}_{\mathbf{1}}$ & $11907 \pm 2068^{\mathrm{c}}$ & $45.35 \pm 4.17^{\mathrm{d}}$ & $23.68 \pm 1.33^{\mathrm{c}}$ \\
$\mathbf{C S}_{\mathbf{2}}$ & $9805 \pm 1335^{\mathrm{bc}}$ & $20.95 \pm 2.90^{\mathrm{a}}$ & $38.24 \pm 1.87^{\mathrm{e}}$ \\
$\mathbf{C S}_{\mathbf{3}}$ & $6408 \pm 565^{\mathrm{ab}}$ & $20.60 \pm 0.00^{\mathrm{a}}$ & $23.34 \pm 1.61^{\mathrm{c}}$ \\
$\mathbf{C S}_{\mathbf{4}}$ & $10406 \pm 1322^{\mathrm{c}}$ & $18.80 \pm 1.13^{\mathrm{a}}$ & $28.89 \pm 3.35^{\mathrm{d}}$ \\
$\mathbf{C S}_{\mathbf{5}}$ & $8452 \pm 1523^{\mathrm{bc}}$ & $21.45 \pm 1.20^{\mathrm{ab}}$ & $32.27 \pm 1.23^{\mathrm{d}}$ \\
$\mathbf{C S}_{\mathbf{6}}$ & $4758 \pm 1602^{\mathrm{a}}$ & $20.75 \pm 2.33^{\mathrm{a}}$ & $9.84 \pm 0.25^{\mathrm{b}}$ \\
$\mathbf{C S}_{\mathbf{7}}$ & $11802 \pm 1482^{\mathrm{c}}$ & $67.25 \pm 3.46^{\mathrm{e}}$ & $41.77 \pm 0.31^{\mathrm{e}}$ \\
$\mathbf{C S}_{\mathbf{8}}$ & $9363 \pm 1787^{\mathrm{bc}}$ & $29.50 \pm 0.28^{\mathrm{c}}$ & $38.35 \pm 1.26^{\mathrm{e}}$ \\
$\mathbf{C S}_{\mathbf{9}}$ & $4339 \pm 580^{\mathrm{a}}$ & $26.00 \pm 0.99^{\mathrm{bc}}$ & $0.00 \pm 0.00^{\mathrm{a}}$ \\
$\mathbf{C S}_{\mathbf{1 0}}$ & $11046 \pm 2596^{\mathrm{c}}$ & $22.95 \pm 0.21^{\mathrm{ab}}$ & $25.08 \pm 2.45^{\mathrm{c}}$ \\
$\mathbf{C S}_{\mathbf{1 1}}$ & $10081 \pm 329^{\mathrm{c}}$ & $42.90 \pm 0.14^{\mathrm{d}}$ & $37.90 \pm 1.28^{\mathrm{e}}$ \\
\hline
\end{tabular}

*Small letters indicate significant differences within each column for the mean \pm SD values calculated from three determinations by one-way ANOVA and Duncan's test $(\mathrm{P} \leq 0.05)$. Cephalaria syriaca L. samples according to location; $\mathrm{CS}_{1}$ : Mardin, $\mathrm{CS}_{2}$ : Van, $\mathrm{CS}_{3}$ : Gaziantep, $\mathrm{CS}_{4}$ : Bitlis, $\mathrm{CS}_{5}$ : Erzincan, $\mathrm{CS}_{6}$ : Diyarbakir, $\mathrm{CS}_{7}$ : Agri, $\mathrm{CS}_{8}$ : Sanliurfa, $\mathrm{CS}_{9}$ : Siirt, $\mathrm{CS}_{10}$ : Mus, $\mathrm{CS}_{11}$ : Batman.

GAE/kg, respectively). The CS seeds in the present study were found to be higher in TCP values.

The DPPH analysis revealed that the samples showed inhibition (radical scavenging effect) between 18.8 and $67.3 \%$. The highest radical scavenging effect was determined in $\mathrm{CS}_{7}$, followed by $\mathrm{CS}_{1}$ and $\mathrm{CS}_{11}$. Rahimi et al., (2019) studied the effect of different fertilizers on the antioxidant capacity of the Cephalaria syriaca plant and concluded that the antioxidant activity of the samples (DPPH) was between 47.10-60.16\%. According to Kaur and Kapoor (2002), DPPH inhibition activity can be classified into three major groups as high $(\geq 50 \%)$, moderate $(20-50 \%)$ and low $(\leq 20 \%)$. Therefore, $\mathrm{CS}_{4}$ was in the low activity group, $\mathrm{CS}_{7}$ was in the high one and the others were in the moderate activity group.

ABTS is often used to test the initial radical scavenging activity of antioxidant compounds or plant extracts. The $\mathrm{ABTS}^{+}$that was obtained as a result of the oxidation of ABTS with potassium persulfate was presented as an excellent tool to determine the antioxidant activity of hydrogen donor antioxidants and chain-breaker antioxidants (Leong and Shui, 2002). The ABTS results (TEAC values) for the seeds, except for $\mathrm{CS}_{9}$, were found between 9.8 and $41.8 \mathrm{mmol}$ Trolox eq/g DW values. The highest TEAC value was found in $\mathrm{CS}_{7}$ : while the lowest was found in $\mathrm{CS}_{6}$. In the case of $\mathrm{CS}_{9}$, no antioxidant activity (TEAC) was detected.

\subsection{Volatile compounds in CS seeds}

The volatile compounds of the CS seeds are given in Table 4; while the GC chromatograms of volatile compounds and detailed information are given in Figure 2. 30 different volatile compounds were detected in the CS seeds collected from the 11 different locations. These consisted of 10 aldehydes, 13 alcohols, 2 monoterpenes, 2 ketones, 1 hydrocarbon, and 1 ester in addition to 1 unidentified species. The total amount of aldehydes in the samples varied between 72.3 and $521.6 \mu \mathrm{g} / \mathrm{kg}$. Total aldehyde values were ordered as $\mathrm{CS}_{8}>\mathrm{CS}_{6}>\mathrm{CS}_{1}>$ $\mathrm{CS}_{9}>\mathrm{CS}_{7}>\mathrm{CS}_{11}>\mathrm{CS}_{4}>\mathrm{CS}_{2}>\mathrm{CS}_{3}>\mathrm{CS}_{10}>\mathrm{CS}_{5}$. The most dominant aldehydes were hexanal, 2-hexenal, butanal 3-methyl, benzaldehyde and acetaldehyde. Nonanal was not detected in $\mathrm{CS}_{1}, \mathrm{CS}_{2}, \mathrm{CS}_{3}$, $\mathrm{CS}_{4}, \mathrm{CS}_{10}$ or $\mathrm{CS}_{11}$ samples. The highest amount of detected aldehyde was hexanal (11.90-162.65 $\mu \mathrm{g} /$ $\mathrm{kg}$ ). The second most dominant component in this group was acetaldehyde and was found in the range of $12.60-54.80 \mu \mathrm{g} / \mathrm{kg}$. The acetaldehyde contents were not different among the samples of $\mathrm{CS}_{2}, \mathrm{CS}_{3}$, $\mathrm{CS}_{4}, \mathrm{CS}_{6}, \mathrm{CS}_{9}, \mathrm{CS}_{10}$ and $\mathrm{CS}_{11 \text {; }}$ whereas differences among other samples were significantly different $(\mathrm{P}<0.05)$. Benzaldehyde was found in all samples and its content was significantly different $(\mathrm{P}<$ 0.05 ). Butanal 3-methyl was the other dominant aldehyde and was detected in the range of 6.6-82.4 $\mu \mathrm{g} / \mathrm{kg}$, significantly different among the samples $(\mathrm{P}<0.05)$. As seen in Table 4 , the total amount of alcohols was higher than aldehydes (81.00$1227.75 \mu \mathrm{g} / \mathrm{kg}$ ). The most dominant compounds in the alcohol group were hexanol, myrtenol and 1-butanol 3-methyl, respectively. The highest value was found in $\mathrm{CS}_{8}$. whereas the lowest value was found in $\mathrm{CS}_{6}$. While the differences among the hexanol values in $\mathrm{CS}_{1}, \mathrm{CS}_{2}, \mathrm{CS}_{3}, \mathrm{CS}_{6}, \mathrm{CS}_{10}$ and $\mathrm{CS}_{11}$ samples were not significant, the mean values for other samples were significantly different $(\mathrm{P}<0.05)$. Myrtenol was detected in all the samples and ranged from 2.6 to $126.3 \mu \mathrm{g} / \mathrm{kg}(\mathrm{P}<0.05)$. In monoterpenes, the $\alpha$-thujene values varied in the range of $0.9-20.6 \mu \mathrm{g} / \mathrm{kg}$ and differed statistically in 
all samples except for $\mathrm{CS}_{1}, \mathrm{CS}_{2}$ and $\mathrm{CS}_{3}(\mathrm{P}<0.05)$. Another monoterpene, $\beta$-pinene, was found to be in the range of $1.10-44.55 \mu \mathrm{g} / \mathrm{kg}$ in all samples $(\mathrm{P}<$ $0.05) . \alpha$-thujene and $\beta$-pinene were determined to be the highest in $\mathrm{CS}_{8}$ (20.60 and $44.55 \mu \mathrm{g} / \mathrm{kg}$, respectively). Metantetranitro was detected in all samples between 10.80 and $34.85 \mu \mathrm{g} / \mathrm{kg}(\mathrm{P}<0.05)$. In general, the total amount of volatile compounds was at the highest level in $\mathrm{CS}_{8}$, collected from the Şanlıurfa province. According to the literature, there was no study on the volatile compounds of CS seeds. As one exception, Sarikahya et al., (2013) investigated the volatile compounds of the essential oil from 10 endemic Cephalaria species, but did not include CS grown in Turkey- A total of 28 components were identified including geraniol, $\alpha$-cedrene and $p$-cymene.

\subsection{Fatty acid composition of CS seed oils}

The fatty acid composition of CS seed oils is given in Table 5. Chromatograms and detailed information are given in Figure 3. The most abundant fatty acid in the CS seed oil was oleic acid (C18:1) followed by linoleic (C18:2), myristic (C14:0) and palmitic (C16:0) acids. Oleic acid varied between 28.10 and $33.22 \%$ and linoleic acid was in the range of $26.84-31.70 \%$ with no statistically significant difference. Yazicioğlu et al., (1978) reported that the oleic acid of oil from CS seeds collected from Kayseri and Diyarbakır (Turkey) was 25.5 and $20.6 \%$; while linoleic acid was 36.3 and $37.6 \%$, respectively. The amounts of oleic acid found in the present study were higher; whereas linoleic acid was lower than these findings. Bretagnolle et al., (2016) reported that oleic and linoleic acids were 19.3 and $42.9 \%$, respectively.

The highest myristic acid content was found in the $\mathrm{CS}_{9}$ sample with $17.30 \%$; whereas the lowest value was found in $\mathrm{CS}_{7}$ at $14.60 \%$, with no statistical difference (Table 5). Yazicioğlu et al., (1978) determined that myristic acid was in the range of 18.4 and $20.5 \%$. In our study, palmitic acid varied between 11.20 and $12.30 \%$, which was not statistically different. Palmitic acid was reported to be $8.8-10.0 \%$ by Yazicioğlu et al., (1978) and $9.5 \%$ by Bretagnolle et al., (2016) in previous studies. We found that stearic acid (C18: 0) was in the range of 3.80-5.20\%. Stearic acid was reported to be in the range of $1.9-2.0 \%$ by Yazicioğlu et al., (1978), and $2.5 \%$ by Bretagnolle et al., (2016). The difference between the samples in terms of linolenic acid was statistically significant $(\mathrm{P}$ $<0.05)$. The highest linolenic acid content $(1.20 \%)$ was found in $\mathrm{CS}_{8}$; while the lowest value $(0.30 \%)$ was determined in $\mathrm{CS}_{2}$ and $\mathrm{CS}_{3}$. Sarikahya et al., (2015) studied the fatty acid composition of the aerial parts of 10 different Cephalaria species, not including CS. In all the species studied, oleic acid was in the range of $10.28-31.65 \%$; while linoleic acid was in the range of 17.81-37.67\%; palmitic acid in the range of $10.54-23.81 \%$; lauric acid in the range of $0.44-$ $2.15 \%$; myristic acid in the range of $2.54-12.79 \%$; stearic acid in the range of $2.35-4.61 \%$; and linolenic acid in the range of $6.29-36.65 \%$. Sarikahya et al., (2015) studied the aerial parts, which usually include leaves, flowers, branches, etc. However, in this study, the fatty acid composition of the seeds was studied, which is the main reason why the results are different from those previously reported. On the other hand, the differences in fatty acid profiles of CS seed oils may be due to factors including species, location, collection time and extraction technique.

The Total saturated fatty acids ( $2 \mathrm{SFA}$ ) of the oil samples ranged between 33.2 and $37.4 \%$; while total monounsaturated fatty acids ( MUFA) varied between 30.5 and $35.1 \%$ and total polyunsaturated fatty acids (EPUFA) were in the range of 27.30$32.90 \%$. Bretagnolle et al., (2016) determined 5 SFA,

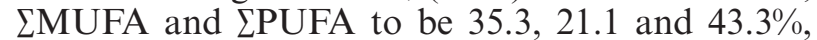
respectively. The American Heart Association and the National Academy of Sciences (First National Academy of Medicine) have recently given dietary recommendations, focusing not only on the amount of fatty acids, but also on the dietary fatty acid types, and often recommend replacing them for MUFA and PUFAs (Krauss et al., 2000). The present study showed that CS species had approximately equal ratios of SFA, MUFA and PUFA. On the other hand, the total content of unsaturated fatty acids was found to be higher than saturated fatty acids, which is generally desirable as a high consumption of saturated fatty acids is shown to be associated with hearth and coronary diseases (Chowdhury et al., 2014). These fatty acids play key roles in human health and growth. It has also been reported that they have positive effects on the prevention and treatment of diseases such as heart and joint diseases, immune system diseases and cancer (Cabre et al., 2012; Gerber, 2012). All of the samples examined can be considered as potentially good for health as the ratio of UFA/SFA in all CS seed oils was greater than 1, and some were close to 2 (Kostić et al., 2017).

\subsection{Peroxide value, free fatty acids and $\alpha$-tocopherol contents of CS seed oils}

The PV of CS seed oils were found between 2.46 and $5.39 \mathrm{meqO}_{2} / \mathrm{kg}$ (Table 6). These values were less than $10 \mathrm{meqO}_{2} / \mathrm{kg}$ (as proposed by the CODEXSTAN 210-1999, Turkish Codex Standards). There was no significant difference among $\mathrm{CS}_{1}, \mathrm{CS}_{3}, \mathrm{CS}_{4}$, $\mathrm{CS}_{6}, \mathrm{CS}_{7}, \mathrm{CS}_{9}, \mathrm{CS}_{10}$ and $\mathrm{CS}_{11}$. The only samples that were significantly different from that group were $\mathrm{CS}_{2}, \mathrm{CS}_{5}$, and $\mathrm{CS}_{8}(\mathrm{P}<0.05)$.

According to O'Brien, (2004), PV is one of the most commonly used parameters to characterize oil quality. $\mathrm{PV}$ in the range of 1 to $5 \mathrm{meqO}_{2} / \mathrm{kg}$ is 
TABLE 4. Volatile compounds $(\mu \mathrm{g} / \mathrm{kg})$ identified in Cephalaria syriaca seeds

\begin{tabular}{|c|c|c|c|c|c|c|}
\hline Compounds & RI & $\mathrm{CS}_{1}$ & $\mathrm{CS}_{2}$ & $\mathrm{CS}_{3}$ & $\mathrm{CS}_{4}$ & $\mathrm{CS}_{5}$ \\
\hline \multicolumn{7}{|l|}{ Aldehydes } \\
\hline Acetaldehyde & 622 & $\mathbf{5 4 . 8 0} \pm 6.12^{\mathrm{d}}$ & $26.20 \pm 1.84^{\mathrm{b}}$ & $24.95 \pm 2.01^{\mathrm{b}}$ & $25.60 \pm 2.56^{\mathrm{b}}$ & $13.70 \pm 0.74^{\mathrm{a}}$ \\
\hline Propanal, 2-methyl & 638 & $8.65 \pm 1.22^{\mathrm{e}}$ & $7.30 \pm 0.49^{\mathrm{de}}$ & $6.00 \pm 1.03^{\mathrm{cd}}$ & $4.40 \pm 0.61^{\mathrm{bc}}$ & $4.65 \pm 0.75^{\mathrm{c}}$ \\
\hline Butanal, 3-methyl & 670 & $25.85 \pm 3.83^{\mathrm{cd}}$ & $22.95 \pm 2.53^{\mathrm{cd}}$ & $18.95 \pm 2.22^{\mathrm{bc}}$ & $24.90 \pm 2.81^{\mathrm{cd}}$ & $6.60 \pm 0.62^{\mathrm{a}}$ \\
\hline Butanal, 2-methyl & 674 & $7.20 \pm 1.10^{\mathrm{bc}}$ & $6.05 \pm 0.21^{\mathrm{b}}$ & $6.60 \pm 0.45^{\mathrm{bc}}$ & $9.75 \pm 1.07^{\mathrm{c}}$ & $7.50 \pm 0.37^{\mathrm{bc}}$ \\
\hline Pentanal & 695 & $2.75 \pm 0.83^{\mathrm{a}}$ & $6.55 \pm 0.68^{\mathrm{c}}$ & $6.95 \pm 0.88^{\mathrm{c}}$ & $6.70 \pm 0.57^{\mathrm{c}}$ & $4.45 \pm 0.51^{\mathrm{b}}$ \\
\hline $\begin{array}{l}\text { 2-Butenal, } \\
\text { 2-methyl }\end{array}$ & 732 & $2.00 \pm 0.18^{\mathrm{a}}$ & $2.05 \pm 0.20^{\mathrm{a}}$ & $1.65 \pm 0.34^{\mathrm{a}}$ & $1.25 \pm 0.24^{\mathrm{a}}$ & $2.20 \pm 0.23^{\mathrm{a}}$ \\
\hline Hexanal & 790 & $25.20 \pm 2.97^{\mathrm{ab}}$ & $33.35 \pm 2.36^{\mathrm{bc}}$ & $29.10 \pm 2.55^{\mathrm{bc}}$ & $42.10 \pm 4.82^{\mathrm{c}}$ & $29.15 \pm 2.97^{\mathrm{bc}}$ \\
\hline 2-Hexenal & 841 & $1.00 \pm 0.11^{\mathrm{a}}$ & --- & --- & $1.45 \pm 0.31^{\mathrm{a}}$ & --- \\
\hline Benzaldehyde & 948 & $22.90 \pm 2.26^{\mathrm{d}}$ & $8.20 \pm 0.82^{\mathrm{b}}$ & $5.50 \pm 0.48^{\mathrm{ab}}$ & $6.00 \pm 0.99^{\mathrm{ab}}$ & $2.65 \pm 0.38^{\mathrm{a}}$ \\
\hline Nonanal & 1090 & --- & --- & --- & --- & $1.35 \pm 0.27^{\mathrm{a}}$ \\
\hline Sum & & $150.35 \pm 3.00^{\mathrm{f}}$ & $112.65 \pm 2.25^{\mathrm{c}}$ & $99.70 \pm 1.61^{b}$ & $122.15 \pm 2.91^{\mathrm{d}}$ & $72.25 \pm 1.85^{\mathrm{a}}$ \\
\hline \multicolumn{7}{|l|}{ Alcohols } \\
\hline Ethanol & 626 & $7.00 \pm 1.17^{\mathrm{cd}}$ & $8.55 \pm 0.72^{\mathrm{de}}$ & $12.35 \pm 0.78^{\mathrm{f}}$ & $4.35 \pm 0.57^{\mathrm{b}}$ & $5.70 \pm 0.71^{\mathrm{bc}}$ \\
\hline $\begin{array}{l}\text { Silanediol, } \\
\text { dimethyl- }\end{array}$ & 690 & $5.10 \pm 0.96^{\mathrm{bc}}$ & $2.85 \pm 0.66^{\mathrm{a}}$ & $6.95 \pm 0.99^{\mathrm{d}}$ & $7.25 \pm 0.65^{\mathrm{d}}$ & $9.05 \pm 0.93^{\mathrm{e}}$ \\
\hline 1-Butanol, 3-Metil & 724 & $9.65 \pm 1.19^{\mathrm{ab}}$ & $6.20 \pm 1.03^{\mathrm{a}}$ & $3.25 \pm 0.68^{\mathrm{a}}$ & $10.90 \pm 1.70^{\mathrm{ab}}$ & $6.60 \pm 0.99^{\mathrm{a}}$ \\
\hline $\begin{array}{l}\text { 1-Butanol, } \\
\text { 2-methyl }\end{array}$ & 727 & $4.60 \pm 0.81^{\mathrm{ab}}$ & $2.50 \pm 0.44^{\mathrm{a}}$ & $2.45 \pm 0.52^{\mathrm{a}}$ & $4.65 \pm 0.52^{\mathrm{ab}}$ & $2.20 \pm 0.27^{\mathrm{a}}$ \\
\hline 1-Pentanol & 756 & $5.65 \pm 0.59^{\mathrm{ab}}$ & $4.80 \pm 0.58^{\mathrm{ab}}$ & $5.45 \pm 0.54^{\mathrm{ab}}$ & $5.10 \pm 0.52^{\mathrm{ab}}$ & $14.60 \pm 0.72^{\mathrm{c}}$ \\
\hline $\begin{array}{l}\text { 1-Pentanol, } \\
\text { 4-methyl }\end{array}$ & 827 & $4.65 \pm 0.59^{\mathrm{b}}$ & $2.15 \pm 0.16^{\mathrm{a}}$ & $4.95 \pm 0.96^{\mathrm{b}}$ & $1.85 \pm 0.40^{\mathrm{a}}$ & --- \\
\hline $\begin{array}{l}\text { 1-Pentanol, } \\
\text { 3-methyl }\end{array}$ & 834 & $13.50 \pm 1.95^{\mathrm{cd}}$ & $4.05 \pm 0.45^{\mathrm{a}}$ & $3.00 \pm 0.27^{\mathrm{a}}$ & $9.65 \pm 1.63^{\mathrm{bc}}$ & $2.30 \pm 0.30^{\mathrm{a}}$ \\
\hline 2-Hexen-1-ol, (E) & 855 & $1.50 \pm 0.01^{\mathrm{a}}$ & $1.50 \pm 0.16^{\mathrm{a}}$ & --- & --- & $0.60 \pm 0.03^{\mathrm{a}}$ \\
\hline Hexanol & 857 & $75.80 \pm 10.86^{\mathrm{a}}$ & $44.30 \pm 3.37^{\mathrm{a}}$ & $56.70 \pm 5.77^{\mathrm{a}}$ & $86.64 \pm 7.10^{\mathrm{ab}}$ & $168.90 \pm 19.23^{\mathrm{c}}$ \\
\hline 1-Octen-3-ol & 968 & $3.20 \pm 0.41^{\mathrm{a}}$ & $4.35 \pm 0.99^{\mathrm{a}}$ & --- & $4.40 \pm 0.40^{\mathrm{a}}$ & $1.95 \pm 0.24^{\mathrm{a}}$ \\
\hline Benzenemethanol & 1022 & $4.10 \pm 0.76^{\mathrm{ab}}$ & --- & --- & --- & --- \\
\hline Isopinocarveol & 1124 & $0.40 \pm 0.08^{\mathrm{a}}$ & --- & --- & --- & --- \\
\hline Myrtenol & 1182 & $57.15 \pm 6.65^{\mathrm{de}}$ & $23.95 \pm 2.67^{b c}$ & $15.35 \pm 1.67^{\mathrm{ab}}$ & $14.80 \pm 1.88^{\mathrm{ab}}$ & $6.15 \pm 0.86^{\mathrm{a}}$ \\
\hline Sum & & $192.30 \pm 4.72^{\mathrm{e}}$ & $105.20 \pm 1.74^{b}$ & $110.45 \pm 2.57^{b}$ & $149.59 \pm 2.67^{d}$ & $218.05 \pm 3.76^{\mathrm{f}}$ \\
\hline \multicolumn{7}{|l|}{ Monoterpenes } \\
\hline$\alpha$-Thujene & 921 & --- & --- & --- & $10.55 \pm 1.92^{\mathrm{b}}$ & $0.90 \pm 0.13^{\mathrm{a}}$ \\
\hline$\beta$-Pinene & 962 & $1.20 \pm 0.27^{\mathrm{a}}$ & $4.35 \pm 0.62^{\mathrm{ab}}$ & $1.10 \pm 0.13^{\mathrm{a}}$ & $17.10 \pm 1.41^{\mathrm{e}}$ & $4.05 \pm 0.34^{\mathrm{ab}}$ \\
\hline Sum & & $1.20 \pm 0.14^{\mathrm{a}}$ & $4.35 \pm 0.42^{\mathrm{ab}}$ & $1.10 \pm 0.14^{\mathrm{a}}$ & $27.65 \pm 1.99^{f}$ & $4.95 \pm 0.30^{\mathrm{bc}}$ \\
\hline \multicolumn{7}{|l|}{ Ketones } \\
\hline 2-propane & 630 & $5.30 \pm 0.41^{b}$ & $8.60 \pm 0.64^{\mathrm{de}}$ & $10.35 \pm 1.74^{\mathrm{ef}}$ & $13.00 \pm 1.46^{\mathrm{g}}$ & $5.95 \pm 0.68^{\mathrm{bc}}$ \\
\hline Acetone & 881 & $1.50 \pm 0.17^{\mathrm{bc}}$ & $1.20 \pm 0.15^{\mathrm{ab}}$ & $1.90 \pm 0.33^{\mathrm{c}}$ & $0.90 \pm 0.16^{\mathrm{ab}}$ & $2.55 \pm 0.37^{\mathrm{d}}$ \\
\hline Sum & & $6.80 \pm 0.54^{b}$ & $9.80 \pm 0.55^{\mathrm{cd}}$ & $12.25 \pm 1.88^{\mathrm{de}}$ & $13.90 \pm 1.64^{\mathrm{e}}$ & $8.50 \pm 1.03^{\mathrm{bc}}$ \\
\hline \multicolumn{7}{|l|}{ Hidrokarbon } \\
\hline Hexane & 647 & $19.35 \pm 2.26^{\mathrm{ab}}$ & $75.60 \pm 5.37^{\mathrm{e}}$ & $32.35 \pm 3.99^{\mathrm{c}}$ & $40.90 \pm 3.24^{\mathrm{d}}$ & $26.90 \pm 3.93^{\mathrm{bc}}$ \\
\hline \multicolumn{7}{|l|}{ Ester } \\
\hline $\begin{array}{l}\text { Acetic acid, ethyl } \\
\text { ester }\end{array}$ & 655 & $3.95 \pm 0.98^{\mathrm{bcd}}$ & $3.60 \pm 0.44^{\mathrm{b}}$ & $3.80 \pm 0.30^{\mathrm{bc}}$ & $8.05 \pm 1.12^{\mathrm{f}}$ & $5.60 \pm 0.83^{\mathrm{de}}$ \\
\hline \multicolumn{7}{|l|}{ Other } \\
\hline Methane, tetranitro & 617 & $18.30 \pm 1.48^{\mathrm{b}}$ & $19.25 \pm 2.21^{\mathrm{b}}$ & $34.85 \pm 3.46^{\mathrm{e}}$ & $24.90 \pm 2.70^{\mathrm{cd}}$ & $25.50 \pm 2.66^{\mathrm{cd}}$ \\
\hline
\end{tabular}

* Small letters indicate significant differences in the same row for the mean \pm SD values calculated from three determinations by one-way $\mathrm{CS}_{4}$ : Bitlis, $\mathrm{CS}_{5}$ : Erzincan, $\mathrm{CS}_{6}$ : Diyarbakir, $\mathrm{CS}_{7}$ : Agri, $\mathrm{CS}_{8}$ : Sanliurfa, $\mathrm{CS}_{9}$ : Siirt, $\mathrm{CS}_{10}$ : Mus, $\mathrm{CS}_{11}$ : Batman. Major consitutents are 


\begin{tabular}{|c|c|c|c|c|c|}
\hline $\mathrm{CS}_{6}$ & $\mathbf{C S}_{7}$ & $\mathrm{CS}_{8}$ & $\mathbf{C S}_{9}$ & $\mathrm{CS}_{10}$ & $\mathrm{CS}_{11}$ \\
\hline $22.80 \pm 2.15^{\mathrm{b}}$ & $12.60 \pm 1.84^{\mathrm{a}}$ & $46.80 \pm 3.90^{\mathrm{c}}$ & $21.95 \pm 2.28^{\mathrm{b}}$ & $28.70 \pm 2.80^{\mathrm{b}}$ & $22.55 \pm 2.32^{\mathrm{b}}$ \\
\hline $11.00 \pm 1.54^{\mathrm{f}}$ & $4.85 \pm 0.30^{c}$ & $\mathbf{1 2 . 6 5} \pm 1.30^{\mathrm{f}}$ & $4.00 \pm 0.33^{\mathrm{bc}}$ & $2.00 \pm 0.14^{\mathrm{a}}$ & $2.60 \pm 0.24^{\mathrm{ab}}$ \\
\hline $21.80 \pm 2.81^{\mathrm{bc}}$ & $38.75 \pm 0.72^{\mathrm{e}}$ & $\mathbf{8 2 . 4 0} \pm 9.57^{\mathrm{f}}$ & $31.35 \pm 3.21^{\mathrm{de}}$ & $13.40 \pm 1.63^{\mathrm{ab}}$ & $25.25 \pm 1.97^{\mathrm{cd}}$ \\
\hline $7.90 \pm 0.41^{\mathrm{bc}}$ & $13.90 \pm 1.02^{\mathrm{d}}$ & $35.30 \pm 3.44^{\mathrm{f}}$ & $9.65 \pm 0.83^{\mathrm{c}}$ & $3.00 \pm 0.59^{\mathrm{a}}$ & $20.35 \pm 2.05^{\mathrm{e}}$ \\
\hline $6.00 \pm 0.48^{\mathrm{bc}}$ & $4.45 \pm 0.62^{\mathrm{b}}$ & $16.70 \pm 1.20^{\mathrm{d}}$ & $2.85 \pm 0.27^{\mathrm{a}}$ & --- & $2.25 \pm 0.18^{\mathrm{a}}$ \\
\hline-- & $1.60 \pm 0.37^{\mathrm{a}}$ & $\mathbf{1 0 . 5 0} \pm 1.17^{\mathrm{b}}$ & $1.60 \pm 0.16^{\mathrm{a}}$ & $1.20 \pm 0.17^{\mathrm{a}}$ & --- \\
\hline $69.25 \pm 5.84^{\mathrm{d}}$ & $23.25 \pm 2.57^{\mathrm{ab}}$ & $\mathbf{1 6 2 . 6 5} \pm 16.39^{\mathrm{e}}$ & $32.25 \pm 3.22^{\mathrm{bc}}$ & $24.10 \pm 2.08^{\mathrm{ab}}$ & $11.90 \pm 0.23^{\mathrm{a}}$ \\
\hline $3.40 \pm 0.44^{\mathrm{a}}$ & $18.20 \pm 0.69^{\mathrm{a}}$ & $\mathbf{1 0 7 . 4 0} \pm 77.46^{\mathrm{b}}$ & $22.95 \pm 2.39^{\mathrm{a}}$ & $0.70 \pm 0.03^{\mathrm{a}}$ & $5.05 \pm 0.48^{\mathrm{a}}$ \\
\hline $6.00 \pm 0.59^{\mathrm{ab}}$ & $16.10 \pm 0.88^{\mathrm{c}}$ & $\mathbf{3 8 . 4 0} \pm 3.89^{\mathrm{f}}$ & $18.00 \pm 1.51^{\mathrm{c}}$ & $5.60 \pm 0.65^{\mathrm{ab}}$ & $31.45 \pm 1.80^{\mathrm{e}}$ \\
\hline $4.65 \pm 0.51^{\mathrm{b}}$ & $1.80 \pm 0.25^{\mathrm{a}}$ & $8.75 \pm 1.00^{c}$ & $1.00 \pm 0.04^{\mathrm{a}}$ & -- & -- \\
\hline $152.80 \pm 2.64^{f}$ & $135.50 \pm 3.24^{\mathrm{e}}$ & $521.55 \pm 9.89^{\mathrm{g}}$ & $145.60 \pm 2.29^{f}$ & $78.70 \pm 2.32^{\mathrm{a}}$ & $121.40 \pm 2.38^{\mathrm{d}}$ \\
\hline $10.45 \pm 1.06^{\mathrm{ef}}$ & $5.80 \pm 0.45^{\mathrm{bc}}$ & $\mathbf{1 7 . 2 5} \pm 1.88^{\mathrm{g}}$ & $6.15 \pm 0.95^{\mathrm{bc}}$ & $5.90 \pm 0.55^{\mathrm{bc}}$ & $2.00 \pm 0.14^{\mathrm{a}}$ \\
\hline $3.80 \pm 0.45^{\mathrm{ab}}$ & $3.20 \pm 0.11^{\mathrm{a}}$ & $6.20 \pm 1.00^{\mathrm{cd}}$ & $3.80 \pm 0.65^{\mathrm{ab}}$ & $4.10 \pm 0.44^{\mathrm{ab}}$ & $3.00 \pm 0.20^{\mathrm{a}}$ \\
\hline $15.55 \pm 1.48^{\mathrm{b}}$ & $32.35 \pm 3.61^{\mathrm{c}}$ & $\mathbf{8 0 . 9 5} \pm 7.78^{\mathrm{e}}$ & $47.65 \pm 3.97^{\mathrm{d}}$ & $6.70 \pm 0.91^{\mathrm{a}}$ & $40.75 \pm 4.09^{\mathrm{d}}$ \\
\hline $7.05 \pm 0.66^{\mathrm{b}}$ & $13.30 \pm 2.93^{\mathrm{c}}$ & $35.70 \pm 3.48^{\mathrm{d}}$ & $14.00 \pm 1.50^{\mathrm{c}}$ & $1.20 \pm 0.14^{\mathrm{a}}$ & $7.55 \pm 0.82^{b}$ \\
\hline $5.85 \pm 0.55^{\mathrm{b}}$ & $3.30 \pm 0.31^{\mathrm{ab}}$ & $30.00 \pm 3.39^{\mathrm{d}}$ & $5.25 \pm 0.51^{\mathrm{ab}}$ & $6.00 \pm 1.22^{\mathrm{b}}$ & $2.85 \pm 0.27^{\mathrm{a}}$ \\
\hline $1.90 \pm 0.40^{\mathrm{a}}$ & $2.40 \pm 0.38^{\mathrm{a}}$ & $12.90 \pm 0.57^{\mathrm{c}}$ & $4.70 \pm 0.72^{\mathrm{b}}$ & $1.50 \pm 0.27^{\mathrm{a}}$ & $4.15 \pm 0.42^{\mathrm{b}}$ \\
\hline $4.50 \pm 0.52^{\mathrm{a}}$ & $15.15 \pm 1.51^{\mathrm{d}}$ & $45.65 \pm 4.53^{\mathrm{e}}$ & $16.50 \pm 1.60^{\mathrm{d}}$ & $6.00 \pm 0.58^{\mathrm{ab}}$ & $10.50 \pm 0.91^{\mathrm{c}}$ \\
\hline $2.75 \pm 0.86^{\mathrm{a}}$ & $15.50 \pm 1.50^{\mathrm{b}}$ & $\mathbf{8 2 . 8 5} \pm 7.45^{\mathrm{d}}$ & $27.20 \pm 2.60^{\mathrm{c}}$ & $0.60 \pm 0.03^{\mathrm{a}}$ & $7.25 \pm 0.74^{\mathrm{a}}$ \\
\hline $35.90 \pm 3.45^{\mathrm{a}}$ & $90.95 \pm 10.54^{\mathrm{ab}}$ & $684.20 \pm 64.83^{\mathrm{d}}$ & $138.20 \pm 13.48^{\mathrm{bc}}$ & $44.70 \pm 4.36^{\mathrm{a}}$ & $59.20 \pm 6.60^{\mathrm{a}}$ \\
\hline $3.30 \pm 0.58^{\mathrm{a}}$ & $90.35 \pm 9.66^{c}$ & $72.00 \pm 6.79^{b}$ & $7.15 \pm 1.06^{\mathrm{a}}$ & $1.70 \pm 0.18^{\mathrm{a}}$ & $4.55 \pm 0.34^{\mathrm{a}}$ \\
\hline $1.70 \pm 0.23^{\mathrm{a}}$ & $8.05 \pm 0.76^{\mathrm{bc}}$ & $16.35 \pm 1.78^{\mathrm{d}}$ & $10.45 \pm 1.10^{\mathrm{c}}$ & --- & $8.65 \pm 3.45^{\mathrm{c}}$ \\
\hline --- & $11.35 \pm 1.00^{\mathrm{c}}$ & $\mathbf{1 7 . 4 0} \pm 1.17^{\mathrm{d}}$ & $4.95 \pm 0.65^{\mathrm{b}}$ & --- & $1.95 \pm 0.16^{\mathrm{a}}$ \\
\hline $30.70 \pm 3.38^{\mathrm{c}}$ & $46.10 \pm 4.70^{\mathrm{d}}$ & $126.30 \pm 12.02^{\mathrm{f}}$ & $65.50 \pm 7.21^{\mathrm{e}}$ & $2.60 \pm 0.47^{\mathrm{a}}$ & $57.20 \pm 5.81^{\mathrm{de}}$ \\
\hline $123.45 \pm 3.90^{c}$ & $337.80 \pm 5.26^{\mathrm{g}}$ & $1227.75 \pm 9.23^{\mathrm{i}}$ & $351.50 \pm 5.81^{h}$ & $81.00 \pm 1.41^{\mathrm{a}}$ & $209.60 \pm 2.81^{f}$ \\
\hline $9.21 \pm 2.26^{\mathrm{b}}$ & $17.70 \pm 1.47^{\mathrm{c}}$ & $20.60 \pm 1.48^{\mathrm{c}}$ & $3.60 \pm 0.31^{\mathrm{a}}$ & $2.70 \pm 0.47^{\mathrm{a}}$ & $1.80 \pm 0.20^{\mathrm{a}}$ \\
\hline $8.85 \pm 0.75^{\mathrm{cd}}$ & $25.60 \pm 2.90^{\mathrm{f}}$ & $44.55 \pm 3.34^{\mathrm{g}}$ & $9.95 \pm 1.22^{\mathrm{d}}$ & $1.30 \pm 0.13^{\mathrm{a}}$ & $5.85 \pm 0.47^{\mathrm{bc}}$ \\
\hline $18.06 \pm 1.30^{\mathrm{e}}$ & $43.30 \pm 1.29^{g}$ & $65.15 \pm 3.20^{\mathrm{h}}$ & $13.55 \pm 1.90^{d}$ & $4.00 \pm 0.17^{\mathrm{ab}}$ & $7.65 \pm 0.44^{\mathrm{c}}$ \\
\hline $12.60 \pm 1.64^{\mathrm{fg}}$ & $7.20 \pm 0.85^{\mathrm{bcd}}$ & $10.50 \pm 0.86^{\mathrm{ef}}$ & $2.50 \pm 0.49^{\mathrm{a}}$ & $8.20 \pm 1.13^{\mathrm{cde}}$ & $5.90 \pm 0.48^{\mathrm{bc}}$ \\
\hline $1.50 \pm 0.23^{\mathrm{bc}}$ & $1.20 \pm 0.18^{\mathrm{ab}}$ & $7.75 \pm 0.66^{\mathrm{e}}$ & $1.20 \pm 0.10^{\mathrm{ab}}$ & $1.00 \pm 0.03^{\mathrm{ab}}$ & $0.60 \pm 0.04^{\mathrm{a}}$ \\
\hline $14.10 \pm 2.22^{\mathrm{e}}$ & $8.40 \pm 0.66^{\mathrm{bc}}$ & $18.25 \pm 1.80^{f}$ & $3.70 \pm 0.13^{\mathrm{a}}$ & $9.20 \pm 0.20^{\mathrm{bc}}$ & $6.50 \pm 0.16^{b}$ \\
\hline $15.00 \pm 1.53^{\mathrm{a}}$ & $27.60 \pm 2.69^{c}$ & $46.65 \pm 4.17^{d}$ & $12.80 \pm 1.24^{\mathrm{a}}$ & $25.00 \pm 2.25^{\mathrm{bc}}$ & --- \\
\hline $6.10 \pm 0.59^{\mathrm{e}}$ & $5.30 \pm 0.61^{\mathrm{cde}}$ & $\mathbf{1 1 . 8 0} \pm 1.15^{\mathrm{g}}$ & $4.10 \pm 0.38^{\mathrm{bcd}}$ & $2.50 \pm 0.27^{\mathrm{ab}}$ & $1.20 \pm 0.13^{\mathrm{a}}$ \\
\hline $20.85 \pm 1.80^{\mathrm{bc}}$ & $22.30 \pm 0.72^{\mathrm{bc}}$ & $28.95 \pm 1.61^{\mathrm{d}}$ & $10.80 \pm 1.56^{\mathrm{a}}$ & $13.55 \pm 1.51^{\mathrm{a}}$ & $13.25 \pm 1.29^{\mathrm{a}}$ \\
\hline
\end{tabular}

ANOVA and Duncan's test $(\mathrm{P} \leq 0.05)$. Cephalaria syriaca $\mathrm{L}$. samples according to location; $\mathrm{CS}_{1}$ : Mardin, $\mathrm{CS}_{2}$ : Van, $\mathrm{CS}_{3}$ : Gaziantep, given in bold font. 

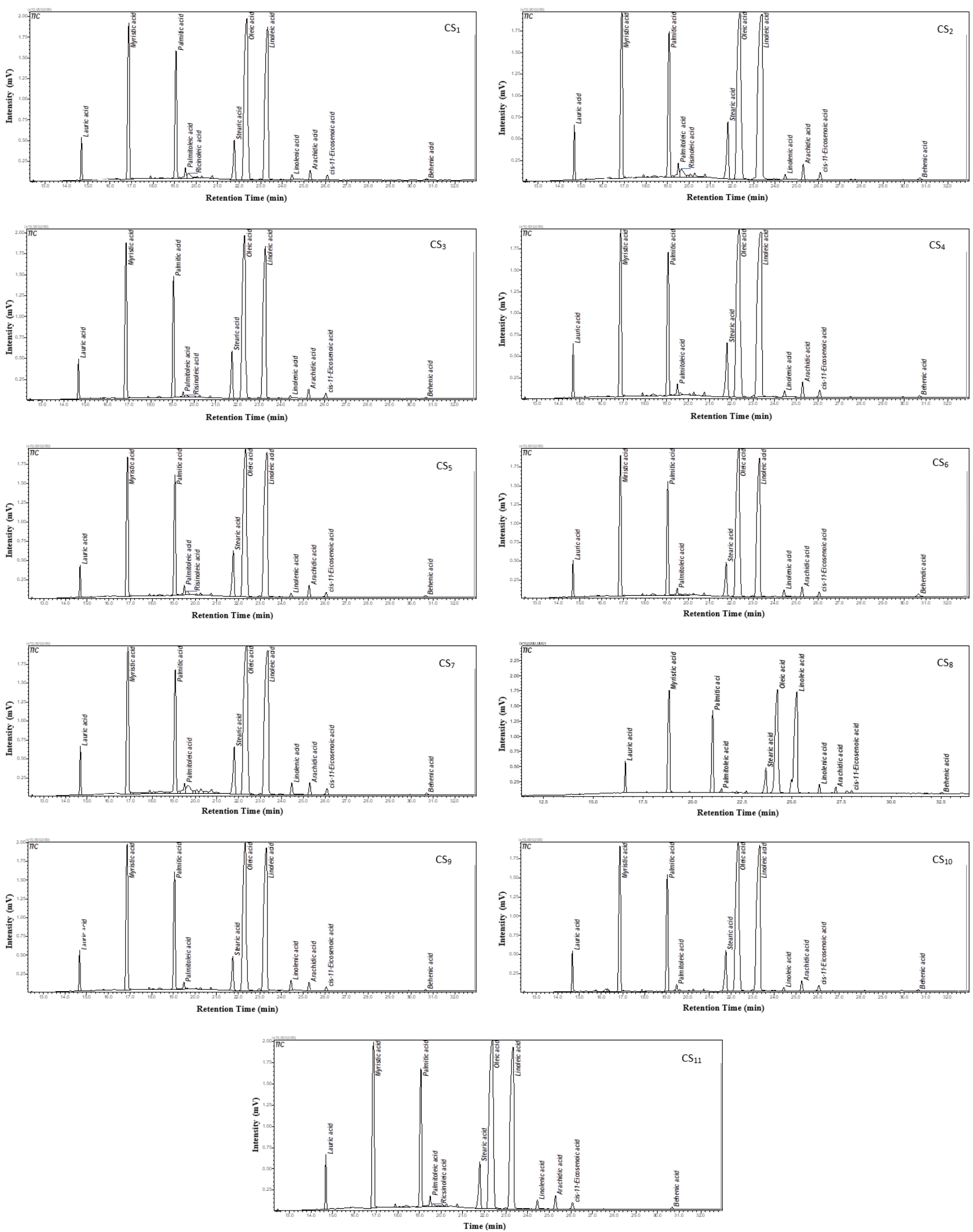

FIGURE 2. GC chromatograms of fatty acid esters obtained from Cephalaria syriaca seed oils. Cephalaria syriaca L. samples according to locations; CS1: Mardin, CS2: Van, CS3: Gaziantep, CS4: Bitlis, CS5: Erzincan, CS6: Diyarbakir, CS7: Agri, CS8: Sanliurfa, CS9: Siirt, CS10: Mus, CS11: Batman 


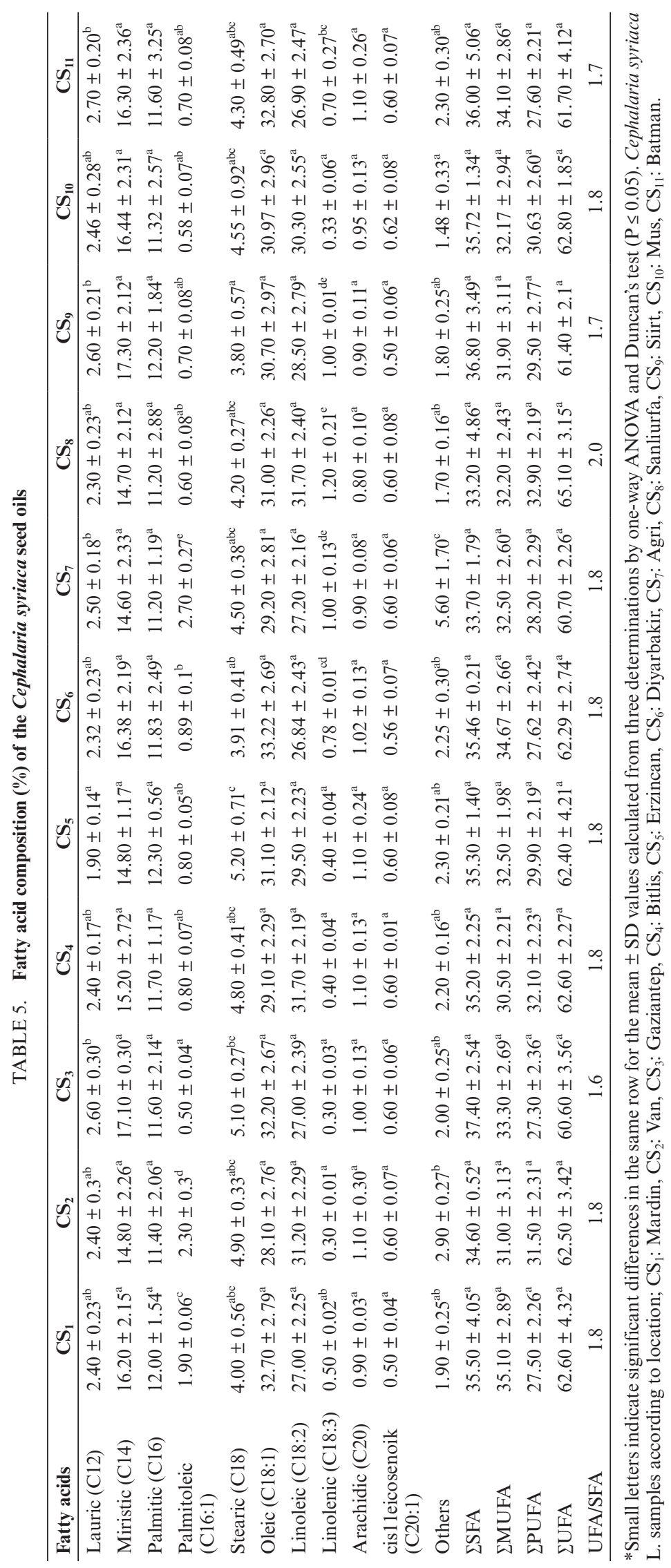



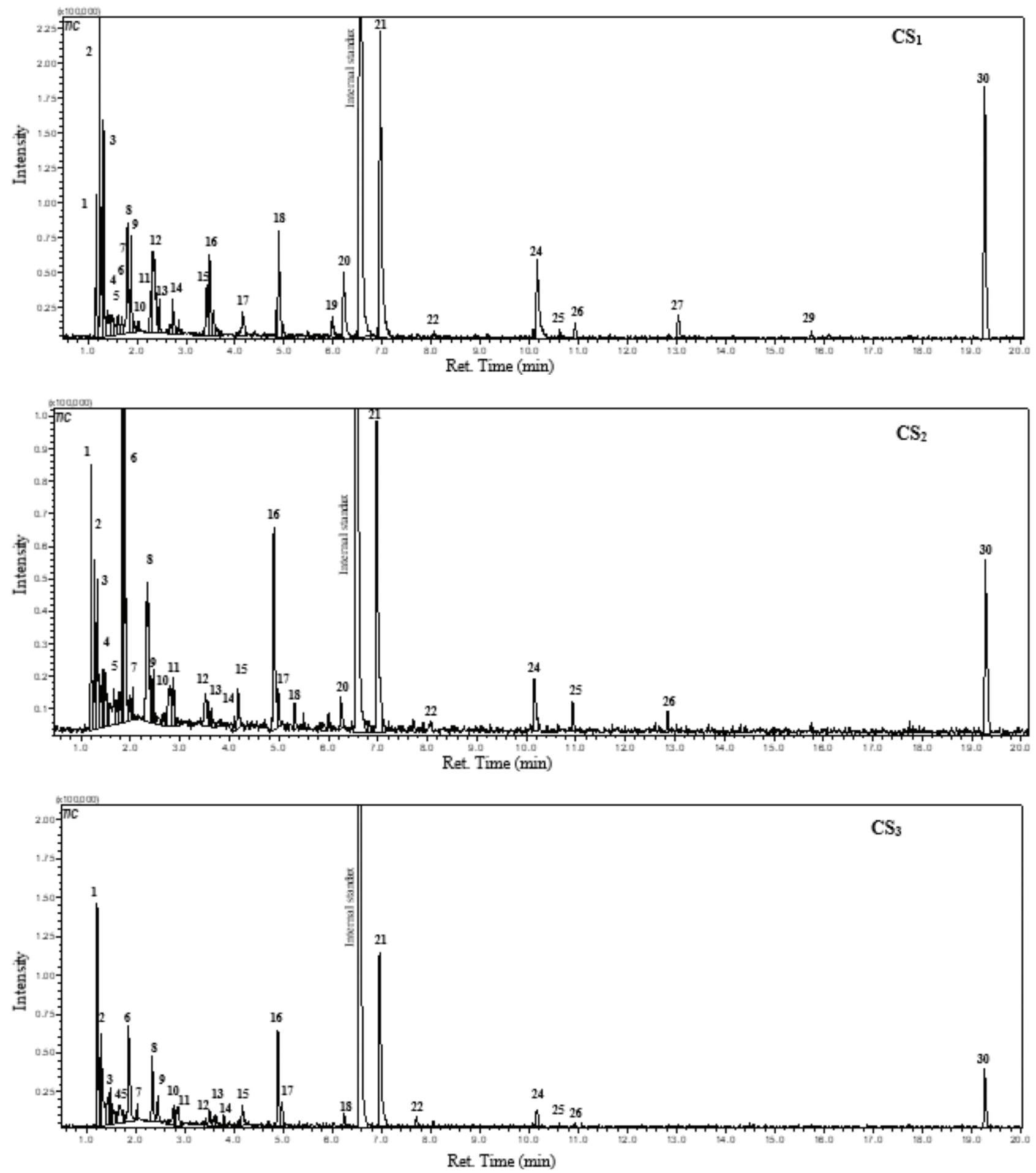

FIGURE 3. GC-MS chromatograms of volatile compounds of Cephalaria syriaca seeds.

1: Methane, tetranitro-; 2: Acetaldehyde; 3: Ethanol; 4: 2 propane; 5: Propanal, 2-methyl-; 6: Butanal, 2-methyl-; 7: Acetic acid, ethyl ester; 8: Butanal, 3-methyl-; 9: Butanal, 2-methyl-; 10: Silanediol, dimethyl-; 11: Pentanal; 12: 1-Butanol, 3-Methyl-;

13: 1-Butanol, 2-methyl-; 14: 2-Butenal, 2-methyl-; 15: 1-Pentanol; 16: Hexanal; 17: 1-Pentanol, 4-methyl-; 18: 1-Pentanol, 3-methyl-; 19: 2-Hexenal; 20: 2-Hexen-1-ol; 21: Hexanol; 22: Acetone; 23: alpha.-Thujene; 24: Benzaldehyde; 25: .beta.-Pinene; 26: 1-Octen-3-ol; 27: Benzenemethanol; 28: Nonanal; 29: Isopinocarveol; 30: Myrtenol. Cephalaria syriaca L. samples according to locations; $\mathrm{CS}_{1}$ : Mardin, $\mathrm{CS}_{2}$ : Van, $\mathrm{CS}_{3}$ : Gaziantep, $\mathrm{CS}_{4}$ : Bitlis, $\mathrm{CS}_{5}$ : Erzincan, $\mathrm{CS}_{6}$ : Diyarbakir, $\mathrm{CS}_{7}$ : Agri, $\mathrm{CS}_{8}$ : Sanliurfa, $\mathrm{CS}_{9}$ : Siirt, $\mathrm{CS}_{10}$ : Mus, $\mathrm{CS}_{11}$ : Batman. 

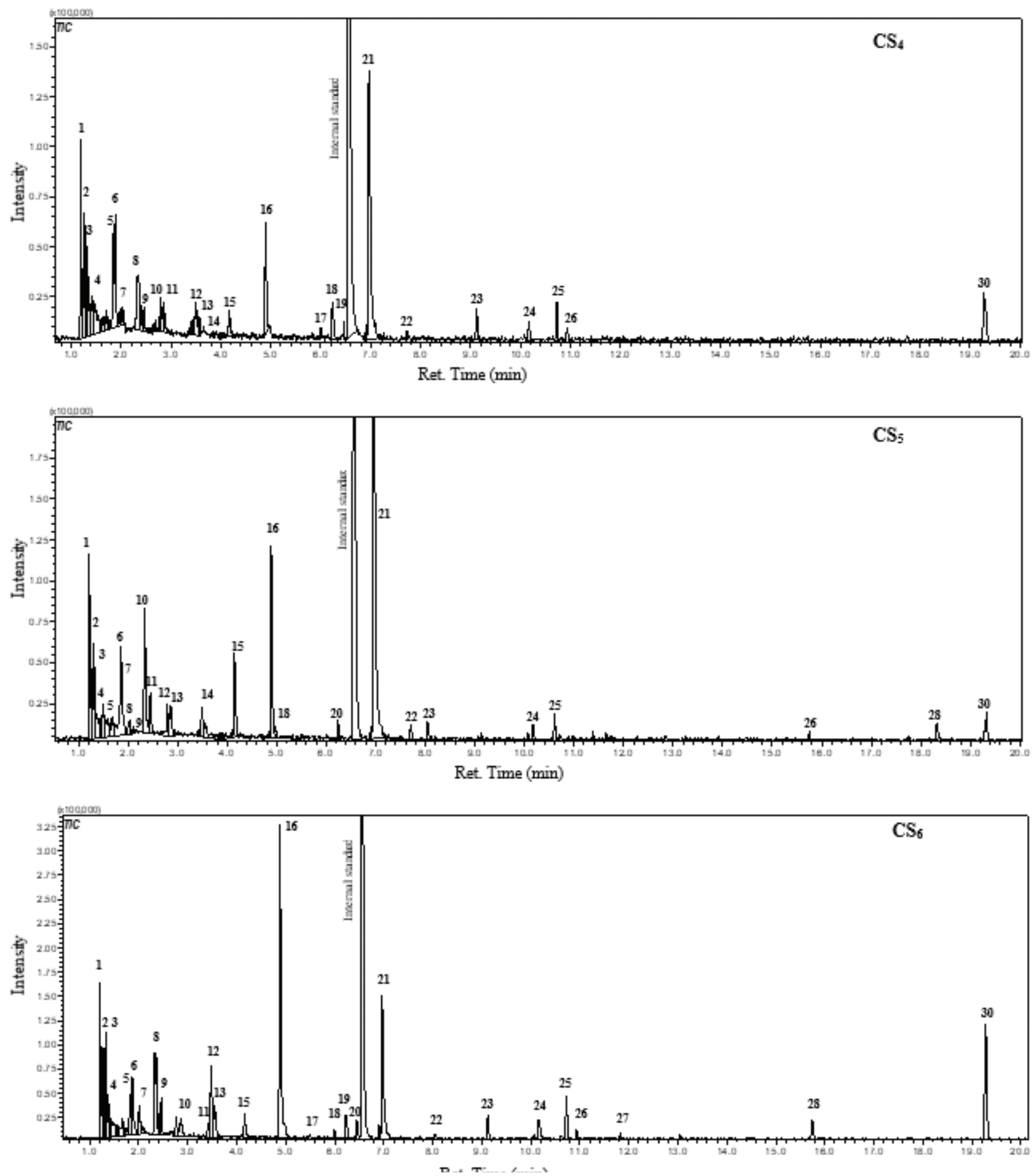

FIGURE 3 (continued). GC-MS chromatograms of volatile compounds of Cephalaria syriaca seeds.

1: Methane, tetranitro-; 2: Acetaldehyde; 3: Ethanol; 4: 2 propane; 5: Propanal, 2-methyl-; 6: Butanal, 2-methyl-; 7: Acetic acid, ethyl ester; 8: Butanal, 3-methyl-; 9: Butanal, 2-methyl-; 10: Silanediol, dimethyl-; 11: Pentanal; 12: 1-Butanol, 3-Methyl-,

13: 1-Butanol, 2-methyl-; 14: 2-Butenal, 2-methyl-; 15: 1-Pentanol; 16: Hexanal; 17: 1-Pentanol, 4-methyl-; 18: 1-Pentanol, 3-methyl-; 19: 2-Hexenal; 20: 2-Hexen-1-ol; 21: Hexanol; 22: Acetone; 23: alpha.-Thujene; 24: Benzaldehyde; 25: beta.-Pinene; 26: 1-Octen-3-ol; 27: Benzenemethanol; 28: Nonanal; 29: Isopinocarveol; 30: Myrtenol. Cephalaria syriaca L. samples according to locations; $\mathrm{CS}_{1}$ : Mardin, $\mathrm{CS}_{2}$ : Van, $\mathrm{CS}_{3}$ : Gaziantep, $\mathrm{CS}_{4}$ : Bitlis, $\mathrm{CS}_{5}$ : Erzincan, $\mathrm{CS}_{6}$ : Diyarbakir, $\mathrm{CS}_{7}$ : Agri, $\mathrm{CS}_{8}$ : Sanliurfa, $\mathrm{CS}_{9}$ : Siirt, $\mathrm{CS}_{10}$ : Mus, $\mathrm{CS}_{11}$ : Batman. 

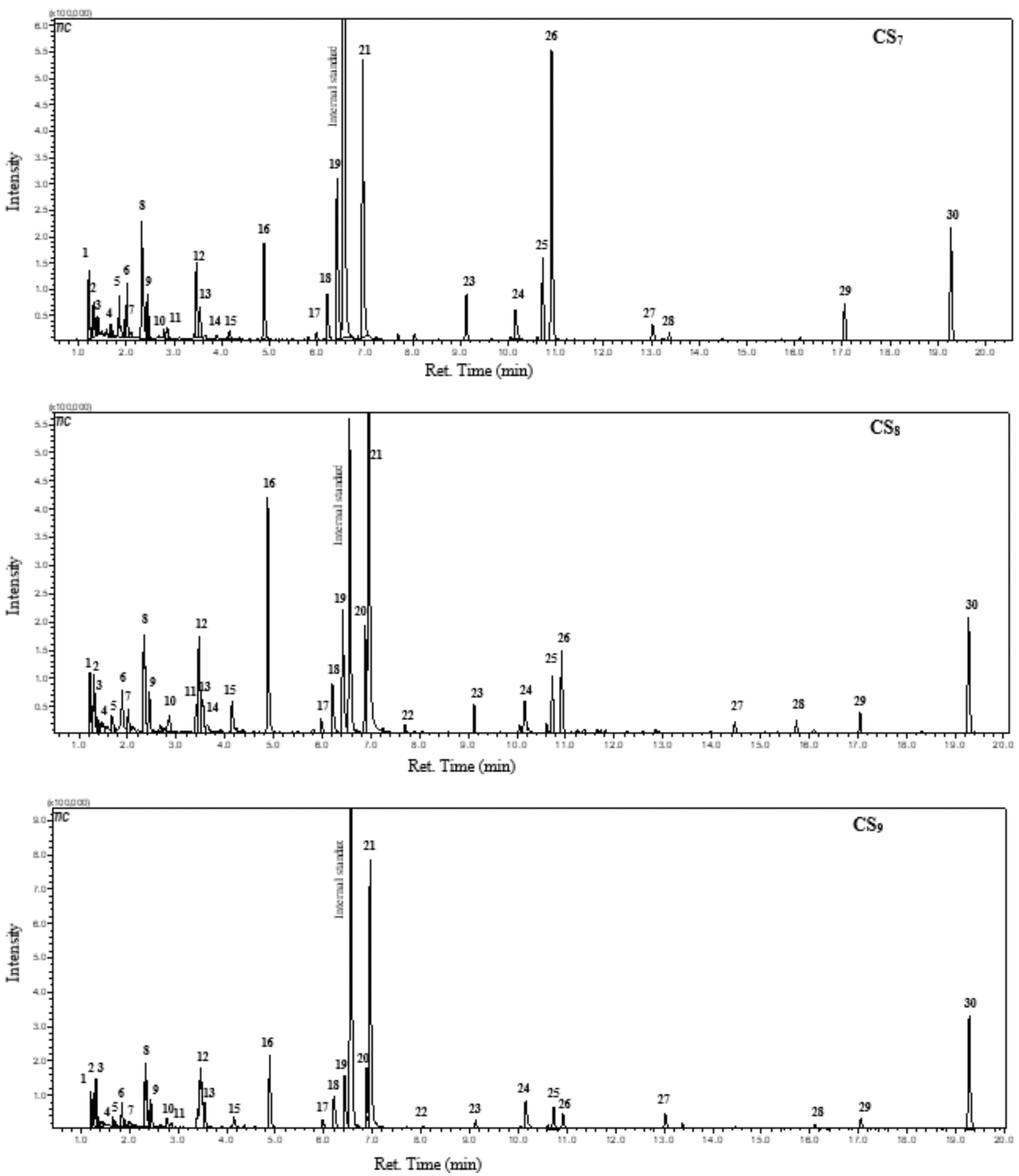

FIGURE 3 (continued). GC-MS chromatograms of volatile compounds of Cephalaria syriaca seeds.

1: Methane, tetranitro-; 2: Acetaldehyde; 3: Ethanol; 4: 2 propane; 5: Propanal, 2-methyl-; 6: Butanal, 2-methyl-; 7: Acetic acid, ethyl ester; 8: Butanal, 3-methyl-; 9: Butanal, 2-methyl-; 10: Silanediol, dimethyl-; 11: Pentanal; 12: 1-Butanol, 3-Methyl-; 13: 1-Butanol, 2-methyl-; 14: 2-Butenal, 2-methyl-; 15: 1-Pentanol; 16: Hexanal; 17: 1-Pentanol, 4-methyl-; 18: 1-Pentanol, 3-methyl-; 19: 2-Hexenal; 20: 2-Hexen-1-ol; 21: Hexanol; 22: Acetone; 23: alpha.-Thujene; 24: Benzaldehyde; 25: beta.-Pinene; 26: 1-Octen-3-ol; 27: Benzenemethanol; 28: Nonanal; 29: Isopinocarveol; 30: Myrtenol. Cephalaria syriaca L. samples according to locations; $\mathrm{CS}_{1}$ : Mardin, $\mathrm{CS}_{2}$ : Van, $\mathrm{CS}_{3}$ : Gaziantep, $\mathrm{CS}_{4}$ : Bitlis, $\mathrm{CS}_{5}$ : Erzincan, $\mathrm{CS}_{6}$ : Diyarbakir, $\mathrm{CS}_{7}$ : Agri, $\mathrm{CS}_{8}$ : Sanliurfa, $\mathrm{CS}_{9}$ : Siirt, $\mathrm{CS}_{10}$ : Mus, $\mathrm{CS}_{11}$ : Batman. 

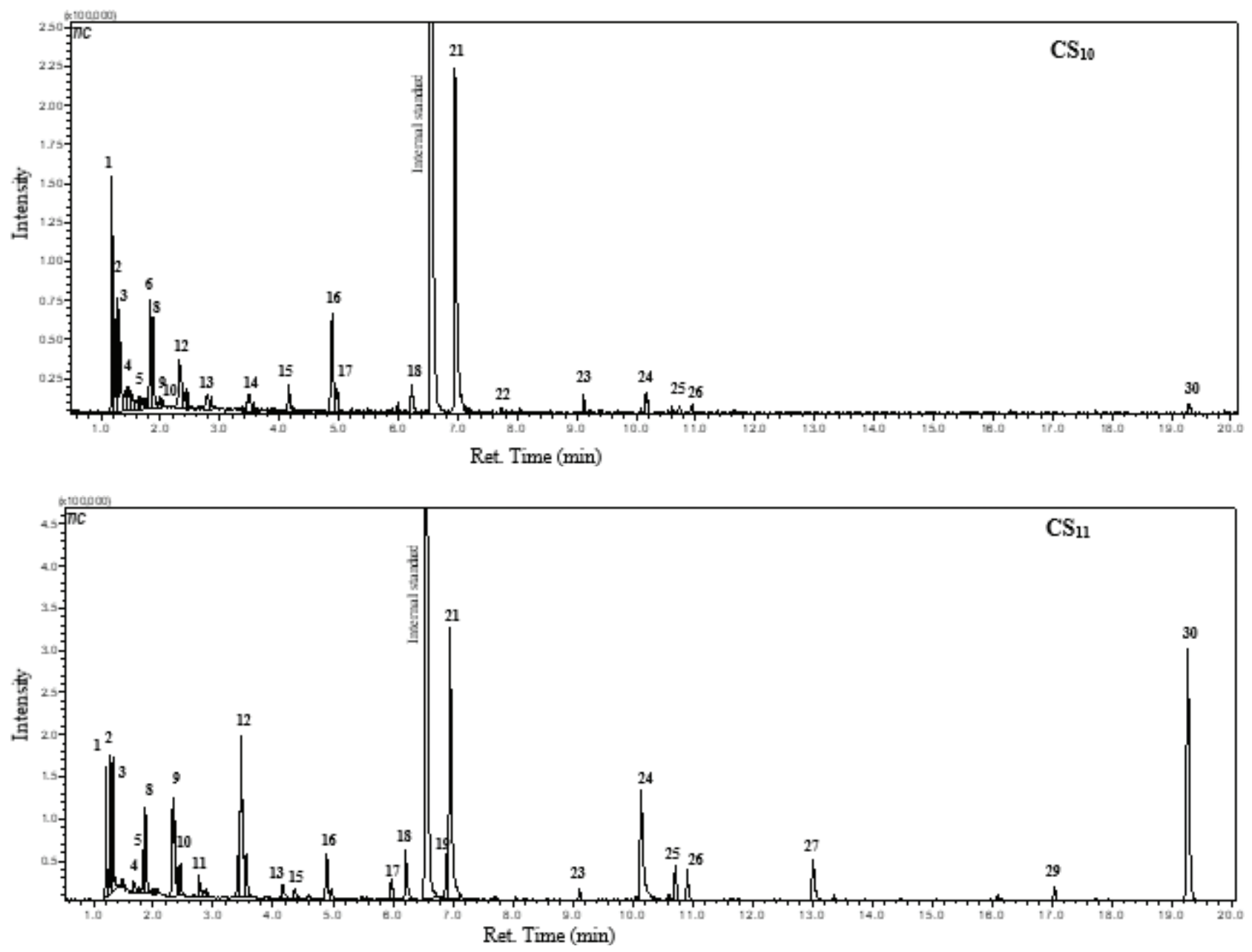

FIGURE 3 (continued). GC-MS chromatograms of volatile compounds of Cephalaria syriaca seeds.

1: Methane, tetranitro-; 2: Acetaldehyde; 3: Ethanol; 4: 2 propane; 5: Propanal, 2-methyl-; 6: Butanal, 2-methyl-; 7: Acetic acid, ethyl ester; 8: Butanal, 3-methyl-; 9: Butanal, 2-methyl-; 10: Silanediol, dimethyl-; 11: Pentanal; 12: 1-Butanol, 3-Methyl-; 13: 1-Butanol, 2-methyl-;

14: 2-Butenal, 2-methyl-; 15: 1-Pentanol; 16: Hexanal; 17: 1-Pentanol, 4-methyl-; 18: 1-Pentanol, 3-methyl-; 19: 2-Hexenal; 20: 2-Hexen-

1-ol; 21: Hexanol; 22: Acetone; 23: alpha.-Thujene; 24: Benzaldehyde; 25: beta.-Pinene; 26: 1-Octen-3-ol; 27: Benzenemethanol; 28 :

Nonanal; 29: Isopinocarveol; 30: Myrtenol. Cephalaria syriaca L. samples according to locations; $\mathrm{CS}_{1}$ : Mardin, $\mathrm{CS}_{2}$ : Van, $\mathrm{CS}_{3}$ : Gaziantep, $\mathrm{CS}_{4}$ : Bitlis, $\mathrm{CS}_{5}$ : Erzincan, $\mathrm{CS}_{6}$ : Diyarbakir, $\mathrm{CS}_{7}$ : Agri, $\mathrm{CS}_{8}$ : Sanliurfa, $\mathrm{CS}_{9}$ : Siirt, $\mathrm{CS}_{10}$ : Mus, $\mathrm{CS}_{11}$ : Batman.

classified as the indication of a low level of oxidation; while $\mathrm{PV}$ between 5 and $10 \mathrm{meqO}_{2} / \mathrm{kg}$ is classified as moderate oxidation and PV in the range of $10-20 \mathrm{meqO}_{2} / \mathrm{kg}$ is classified as having a high level of oxidation. In this study, all the samples, except for $\mathrm{CS}_{5}$ and $\mathrm{CS}_{8}$, can be considered to not exceed the level of low oxidation as those samples were high in UFA compared to other samples.

FFA were found in the range of $0.27-0.83$ (as $\%$ oleic acid) except for $\mathrm{CS}_{5}$. In the case of $\mathrm{CS}_{5}$, this value was determined to be 2.38 . In the literature, there was no study investigating the FFA or PV of CS seed oil. CS seed oils were found to contain $\alpha$-tocopherol between 54 and $467 \mathrm{mg} / \mathrm{kg}$; whereas other tocopherol analogs were not found (Table 6). The highest $\alpha$-tocopherol was detected in $\mathrm{CS}_{6}(467 \mathrm{mg} / \mathrm{kg})$; whereas the lowest was found in $\mathrm{CS}_{7}(54 \mathrm{mg} / \mathrm{kg})$. The range of $\alpha$-tocopherols in our study is much higher than that in the refined oils of corn $(3.11-4.46 \mathrm{mg} / \mathrm{kg})$, soybean $(1.19-1.42 \mathrm{mg} / \mathrm{kg})$, sunflower $(9.52-11.4 \mathrm{mg} / \mathrm{kg})$ and canola $(3.82-4.95$ $\mathrm{mg} / \mathrm{kg}$ ) (Castelo-Branco et al., 2016). Compared with other common vegetable oils, CS seed oil can be considered a good source of $\alpha$-tocopherol. The differences in the contents of $\alpha$-tocopherol in the CS seed oils under study may be due to differences in cultivar, variety and origin of the investigated CS seeds. According to the literature, there was no study investigating the $\alpha$-tocopherol content of CS seed oil.

\subsection{Color parameters of CS seed oils}

The color characteristics of foods are important and greatly affect consumer preference (Faustman and Cassens, 1990). The L*, a* and b* 
TABLE 6. Peroxide value, free fatty acid and $\alpha$-tocopherol content of Cephalaria syriaca seed oils

\begin{tabular}{lccc}
\hline Sample & $\begin{array}{c}\text { PV } \\
\left(\mathbf{m e q} \mathbf{O}_{2} / \mathbf{k g}\right)\end{array}$ & $\begin{array}{c}\text { FFA free fatty acid } \\
(\text { oleic acid \%) }\end{array}$ & $\begin{array}{c}\boldsymbol{\alpha} \text {-tocopherol } \\
(\mathbf{m g} / \mathbf{k g})\end{array}$ \\
\hline $\mathrm{CS}_{1}$ & $2.64 \pm 0.04^{\mathrm{ab}}$ & $0.28 \pm 0.04^{\mathrm{a}}$ & $368 \pm 15.13^{\mathrm{d}}$ \\
$\mathrm{CS}_{2}$ & $3.97 \pm 0.13^{\mathrm{bc}}$ & $0.28 \pm 0.01^{\mathrm{a}}$ & $70 \pm 2.33^{\mathrm{ab}}$ \\
$\mathrm{CS}_{3}$ & $3.93 \pm 1.50^{\mathrm{abc}}$ & $0.28 \pm 0.00^{\mathrm{a}}$ & $395 \pm 18.53^{\mathrm{d}}$ \\
$\mathrm{CS}_{4}$ & $3.86 \pm 0.02^{\mathrm{abc}}$ & $0.27 \pm 0.08^{\mathrm{a}}$ & $464 \pm 15.77^{\mathrm{f}}$ \\
$\mathrm{CS}_{5}$ & $5.39 \pm 0.67^{\mathrm{d}}$ & $2.38 \pm 0.27^{\mathrm{e}}$ & $332 \pm 10.75^{\mathrm{c}}$ \\
$\mathrm{CS}_{6}$ & $3.82 \pm 0.11^{\mathrm{ab}}$ & $0.27 \pm 0.06^{\mathrm{a}}$ & $467 \pm 12.3^{\mathrm{f}}$ \\
$\mathrm{CS}_{7}$ & $3.43 \pm 0.70^{\mathrm{ab}}$ & $0.70 \pm 0.01^{\mathrm{cd}}$ & $54 \pm 1.98^{\mathrm{a}}$ \\
$\mathrm{CS}_{8}$ & $5.30 \pm 0.59^{\mathrm{cd}}$ & $0.83 \pm 0.13^{\mathrm{d}}$ & $85 \pm 3.04^{\mathrm{b}}$ \\
$\mathrm{CS}_{9}$ & $2.80 \pm 0.02^{\mathrm{ab}}$ & $0.56 \pm 0.16^{\mathrm{bc}}$ & $458 \pm 12.59^{\mathrm{ef}}$ \\
$\mathrm{CS}_{10}$ & $2.46 \pm 0.70^{\mathrm{a}}$ & $0.28 \pm 0.07^{\mathrm{a}}$ & $382 \pm 11.53^{\mathrm{d}}$ \\
$\mathrm{CS}_{11}$ & $3.91 \pm 0.01^{\mathrm{abc}}$ & $0.42 \pm 0.08^{\mathrm{ab}}$ & $433 \pm 12.88^{\mathrm{e}}$ \\
\hline
\end{tabular}

*Small letters indicate significant differences within each column for the mean \pm SD values calculated from three determinations by one-way ANOVA and Duncan's test $(\mathrm{P} \leq 0.05)$. Cephalaria syriaca $\mathrm{L}$. samples according to location; $\mathrm{CS}_{1}$ : Mardin, $\mathrm{CS}_{2}$ : Van, $\mathrm{CS}_{3}$ : Gaziantep, $\mathrm{CS}_{4}$ : Bitlis, $\mathrm{CS}_{5}$ : Erzincan, $\mathrm{CS}_{6}$ : Diyarbakir, $\mathrm{CS}_{7}$ : Agri, $\mathrm{CS}_{8}$ : Sanliurfa, $\mathrm{CS}_{9}$ : Siirt, $\mathrm{CS}_{10}$ : Mus, $\mathrm{CS}_{11}$ : Batman.

TABLE 7. Color values of Cephalaria syriaca seed oils

\begin{tabular}{lccc}
\hline \multicolumn{1}{r}{ Sample } & $\mathbf{L}^{*}$ & $\mathbf{a}^{*}$ & $\mathbf{b}^{*}$ \\
\hline $\mathrm{CS}_{1}$ & $23.73 \pm 0.14^{\mathrm{d}}$ & $-0.94 \pm 0.10^{\mathrm{a}}$ & $10.15 \pm 0.10^{\mathrm{de}}$ \\
$\mathrm{CS}_{2}$ & $23.83 \pm 0.49^{\mathrm{de}}$ & $-1.01 \pm 0.20^{\mathrm{a}}$ & $13.32 \pm 0.74^{\mathrm{f}}$ \\
$\mathrm{CS}_{3}$ & $24.80 \pm 0.28^{\mathrm{e}}$ & $0.02 \pm 0.13^{\mathrm{b}}$ & $10.22 \pm 0.02^{\mathrm{de}}$ \\
$\mathrm{CS}_{4}$ & $24.23 \pm 0.71^{\mathrm{de}}$ & $0.88 \pm 0.23^{\mathrm{c}}$ & $9.39 \pm 0.07^{\mathrm{d}}$ \\
$\mathrm{CS}_{5}$ & $24.87 \pm 0.12^{\mathrm{e}}$ & $-0.81 \pm 0.01^{\mathrm{a}}$ & $10.60 \pm 0.04^{\mathrm{e}}$ \\
$\mathrm{CS}_{6}$ & $20.23 \pm 0.04^{\mathrm{c}}$ & $1.69 \pm 0.08^{\mathrm{d}}$ & $7.99 \pm 0.21^{\mathrm{c}}$ \\
$\mathrm{CS}_{7}$ & $18.63 \pm 1.03^{\mathrm{a}}$ & $1.81 \pm 0.02^{\mathrm{d}}$ & $4.73 \pm 0.33^{\mathrm{a}}$ \\
$\mathrm{CS}_{8}$ & $20.13 \pm 0.21^{\mathrm{c}}$ & $2.37 \pm 0.40^{\mathrm{e}}$ & $8.16 \pm 0.74^{\mathrm{c}}$ \\
$\mathrm{CS}_{9}$ & $18.79 \pm 0.21^{\mathrm{ab}}$ & $2.04 \pm 0.35^{\mathrm{de}}$ & $5.94 \pm 0.27^{\mathrm{b}}$ \\
$\mathrm{CS}_{10}$ & $24.00 \pm 0.39^{\mathrm{de}}$ & $0.60 \pm 0.02^{\mathrm{c}}$ & $10.06 \pm 0.19^{\mathrm{de}}$ \\
$\mathrm{CS}_{11}$ & $19.75 \pm 0.03^{\mathrm{bc}}$ & $1.71 \pm 0.48^{\mathrm{d}}$ & $6.44 \pm 0.54^{\mathrm{b}}$ \\
\hline
\end{tabular}

*Small letters indicate significant differences within each column for the mean \pm SD values calculated from three determinations by one-way ANOVA and Duncan's test $(\mathrm{P} \leq 0.05)$. Cephalaria syriaca samples according to location; $\mathrm{CS}_{1}$ : Mardin, $\mathrm{CS}_{2}$ : Van, $\mathrm{CS}_{3}$ : Gaziantep, $\mathrm{CS}_{4}$ : Bitlis, $\mathrm{CS}_{5}$ : Erzincan, $\mathrm{CS}_{6}$ : Diyarbakir, $\mathrm{CS}_{7}$ : Agri, $\mathrm{CS}_{8}$ : Sanliurfa, $\mathrm{CS}_{9}$ : Siirt, $\mathrm{CS}_{10}$ : Mus, $\mathrm{CS}_{11}$ : Batman.

color parameters of the seed oil samples are given in Table $7 . \mathrm{L}^{*}$ values significantly varied between 18.63 and $24.87(\mathrm{P}<0.05)$. The highest $\mathrm{L}^{*}$ value (maximum brightness) was found in $\mathrm{CS}_{5}$ seed oil; whereas the lowest was in $\mathrm{CS}_{7}$. $\mathrm{a}^{*}$ values were found between -1.01 and $2.37(\mathrm{P}<0.05)$. $\mathrm{CS}_{8}$ had the highest redness; whereas $\mathrm{CS}_{2}$ had the lowest. In addition, $\mathrm{CS}_{1}, \mathrm{CS}_{2}$, and $\mathrm{CS}_{5}$ samples were on the green side of the scale. Differences between $\mathrm{b}^{*}$ values were significant $(\mathrm{P}<0.05)$. As indicated in Table 7, the $b^{*}$ values of the samples were in the range of 4.73-13.32. The highest $b^{*}$ value was in $\mathrm{CS}_{2}$; while the lowest was detected in $\mathrm{CS}_{7}$. Differences between these parameters were associated with location, soil and climatic conditions, probably due to geographic locations from where the plants were collected.

\section{CONCLUSIONS}

The results obtained in this study revealed that CS seeds were high in oil content, varying in the range of $11.2-24.0 \%$, which seems to be a significant source of oleic and linoleic acids. Extraction yield of the oil samples varied according to location, and $\mathrm{CS}_{1}$ and $\mathrm{CS}_{11}$ samples in particular are significantly different form all the other samples. It was determined that the PV and FFA levels of the oil samples were within the limits given in the standards. $\mathrm{CS}_{11}, \mathrm{CS}_{6}, \mathrm{CS}_{10}$ and $\mathrm{CS}_{1}$ were found to have the highest protein contents $(21 \%$ on average). It was seen that the highest levels of TPC and antioxidant capacity among the CS seeds were found in the samples $\mathrm{CS}_{1}, \mathrm{CS}_{7}$, and $\mathrm{CS}_{11}$. A total of 30 different volatile compounds were identified in the samples, dominated by alcohols and aldehydes. CS 
seed oils were found to contain $\alpha$-tocopherol between 54 and $467 \mathrm{mg} / \mathrm{kg}$; whereas other tocopherol analogs were not found. The results of this study showed that CS seeds can be considered as an alternative raw material for the production of edible oil. In addition, the oil can be used as a natural antioxidant and food additive for pharmacology and the food industry because of its relatively high antioxidant capacity. Further studies are needed to isolate and characterize the active compounds that are responsible from its promising antioxidant activity.

\section{ACKNOWLEDGMENTS}

This research was supported by the Scientific Research Fund of Van Yüzüncü Yil University [grant numbers FYL-2017-5788].

\section{REFERENCES}

Altıniğne N, Saygın E. 1985. Pelemir Katımlı Undan Yapılan Ekmeklerde Bayatlama Süresi. Gıda Dergisi 10.

AOAC 2005, Determination of moisture, ash, protein and fat, 18th edn. Association of Official Analytical Chemists, Washington, USA

AOCS 1989b, Official Method Cd 8b-90. Peroxide value, acetic acidisooctane method. In: Official methods and recommended practices of the Am. Oil Chem. Soc. (4th ed.), AOCS Champaign, IL, USA.

AOCS 2003, Official Method Ce 8-89. Determination of tocopherols and tocotrienols in vegetable oils and fats by HPLC. In: Official methods and recommended practices of the Am. Oil Chem. Soc. (4th ed.), AOCS, Champaign, IL, USA.

Basturk A, Javidipour I, Boyaci IH. 2007. Oxidative stability of natural and chemically interesterified cottonseed, palm and soybean oils. J. Food Lipids 14, 170-88. https://doi. org/10.1111/j.1745-4522.2007.00078.x

Blois MS. 1958. Antioxidant determinations by the use of a stable free radical. Nature 181, 1199-200.

Bretagnolle F, Matejicek A, Gregoire S, Reboud X, Gaba S. 2016. Determination of fatty acids content, global antioxidant activity and energy value of weed seeds from agricultural fields in France. Weed Research 56, 78-95. https://doi. org/10.1111/wre. 12188

Cabre E, Manosa M, Gassull MA. 2012. Omega-3 fatty acids and inflammatory bowel diseases - a systematic review. Br. J. Nutr. 107 Suppl 2, S240-52. https://doi.org/10.1017/ S0007114512001626

Castelo-Branco VN, Santana I, Di-Sarli VO, Freitas SP, Torres AG. 2016. Antioxidant capacity is a surrogate measure of the quality and stability of vegetable oils. Eur. J. Lipid Sci. Technol.118,224-235. https://doi.org/10.1002/ejlt.201400299

Chowdhury R, Warnakula S, Kunutsor S, Crowe F, Ward HA, Johnson L, Franco OH, Butterworth AS, Forouhi NG, Thompson SG. 2014. Association of dietary, circulating, and supplement fatty acids with coronary risk: a systematic review and meta-analysis. Annals Internal Medi. https:// doi.org/10.7326/M13-1788

Davis PH. 1970. Flora of Turkey and the East Aegean Islands. Edinburgh University Press 3.

Faustman C, Cassens R. 1990. The biochemical basis for discoloration in fresh meat: a review. J. Muscle Foods 1, 217-43. https://doi.org/10.1111/j.1745-4573.1990.tb00366.x

Gerber M. 2012. Omega-3 fatty acids and cancers: a systematic update review of epidemiological studies. Br. J. Nutr. 107 Suppl 2, S228-39. https://doi.org/10.1017/S0007114512001614

Gokturk RS, Sumbul H. 2014. A taxonomic revision of the genus Cephalaria (Caprifoliaceae) in Turkey. Turkish J. Botany 38, 927-68. https://doi org/10.3906/bot-1310-6

Gokturk RS, Sumbul H, Acik L. 2003. A new species of Cephalaria Schrader ex Roemer \& Schultes (Dipsacaceae), including a new variety from East Anatolia, Turkey. Israel J. Plant. Sci. 51, 59-65.

Katar D, Arslan Y, Subasi I, Kodas R. 2012. The effect of different sowing dates on yield and yield components of Cephalaria (Cephalaria syriaca) under Ankara/Turkey ecological condition. Biolog. Diver. Conserv. 5, 48-53.

Kaur C, Kapoor HC. 2002. Anti-oxidant activity and total phenolic content of some Asian vegetables. Int. J. Food Sc. Technol. 37, 153-61. https://doi.org/10.1046/j.1365-2621.2002.00552.x

Kayce P, Kirmizigül S. 2010. Chemical constituents of two endemic Cephalaria species. Records Nat. Prod. 4, 141

Kirmizigül S, Anil H, Uçar F, Akdemir K. 1996. Antimicrobial and antifungal activities of three new triterpenoid glycosides. Phytotherapy Res. 10, 274-6. https://doi. org/10.1002/(SICI)1099-1573(199605)10:3<274::AIDPTR822>3.0. CO;2-V

Kostić AŽ, Mačukanović-Jocić MP, Trifunović BDŠ, Vukašinović IŽ, Pavlović VB, Pešić MB. 2017. Fatty acids of maize pollen-Quantification, nutritional and morphological evaluation. J. Cereal Sc. 77, 180-5. https://doi. org/10.1016/j.jcs.2017.08.004

Krauss RM, Eckel RH, Appel LJ, Daniels SR, Deckelbaum RJ, Erdman Jr JW, Goldberg IJ, Kotchen TA, Lichtenstein AH, Mitch WE. 2000. AHA dietary guidelines. Stroke.

Krist S, Stuebiger G, Bail S, Unterweger H. 2006. Analysis of volatile compounds and triacylglycerol composition of fatty seed oil gained from flax and false flax. Eur. J. Lipid Sci. Technol. 108, 48-60. https://doi.org/10.1002/ejlt.200500267

Leong L, Shui G. 2002. An investigation of antioxidant capacity of fruits in Singapore markets. Food Chem. 76, 69-75. https://doi.org/10.1016/S0308-8146(01)00251-5

Mustafaeva K, Elias R, Balansard G, Suleimanov T, Mayu-Lede V, Kerimov Y. 2008. Iridoid glycosides from Cephalaria kotschyi roots. Chem. Nat. Comp. 44, 132-3.

Nehdi IA. 2011. Characteristics and composition of Washingtonia filifera (Linden ex André) $H$. Wendl. seed and seed oil. Food Chem. 126, 197-202. https://doi. org/10.1016/j.foodchem.2010.10.099

O'Brien R. 2004. Fats and Oils-Formulating and Processing for Applications CRC Press. Boca Raton, Florida.

Pasi S, Aligiannis N, Pratsinis H, Skaltsounis A-L, Chinou IB. 2009. Biologically active triterpenoids from Cephalaria ambrosioides. Plant. Med. 75, 163-7. https://doi.org/ $10.1055 / \mathrm{s}-0028-1088391$

Rahimi A, Moghaddam SS, Ghiyasi M, Heydarzadeh S, Ghazizadeh K, Popović-Djordjević J. 2019. The Influence of Chemical, Organic and Biological Fertilizers on Agrobiological and Antioxidant Properties of Syrian Cephalaria (Cephalaria syriaca L.). Agriculture 9, 122. https://doi.org/10.3390/agriculture9060122

Re R, Pellegrini N, Proteggente A, Pannala A, Yang M, Rice-Evans C. 1999. Antioxidant activity applying an improved ABTS radical cation decolorization assay. Free Rad. Biol. Med. 26, 1231-7. https://doi.org/10.1016/ S0891-5849(98)00315-3

Sarkahya NB, Kayce P, Halay E, Göktürk R, Sümbül H, Kırmızıgül S. 2013. Phytochemical analysis of the essential oils of 10 endemic Cephalaria species from Turkey. Nat. Product Res. 27, 830-3. https://doi.org/10.1080/14786419. 2012.701216

Sarikahya NB, Ucar EO, Kayce P, Gokturk RS, Sumbul H, Arda N, Kirmizigul S. 2015. Fatty Acid Composition and Antioxidant Potential of Ten Cephalaria Species. Records Nat. Prod 9, 116-23.

Sarıkahya NBk, Kırmızıgül Sh. 2010. Antimicrobial triterpenoid glycosides from Cephalaria scoparia. J. Nat. Prod. 73, 825-30. https://doi.org/10.1021/np900724u

Singleton VL, Rossi JA. 1965. Colorimetry of total phenolics with phosphomolybdic-phosphotungstic acid reagents. Am. J. Enol. Vit. 16, 144-58.

Uslu ES. 2016. Zayıf unların ekmeklik kalitelerinin pelemir (Cephalaria syriaca) ekstraktı ilavesiyle geliştirilmesi (Doctoral dissertation).

Yazicioğlu T, Karaali A, Gökçen J. 1978. Cephalaria syriaca seed oil. J. Am. Oil Chem. Soc. 55, 412-5. https://doi. org/10.1007/BF02911903 